FEDERAL RESERVE BANK OF SAN FRANCISCO

WORKING PAPER SERIES

\title{
Sovereign Wealth Funds: Stylized Facts about their Determinants and Governance
}

\author{
Joshua Aizenman \\ University of California, Santa Cruz \\ Reuven Glick \\ Federal Reserve Bank of San Francisco
}

December 2008

Working Paper 2008-33

http://www.frbsf.org/publications/economics/papers/2008/wp08-33bk.pdf

The views in this paper are solely the responsibility of the authors and should not be interpreted as reflecting the views of the Federal Reserve Bank of San Francisco or the Board of Governors of the Federal Reserve System. This paper was produced under the auspices of the Center for Pacific Basin Studies within the Economic Research Department of the Federal Reserve Bank of San Francisco. 
Sovereign Wealth Funds: Stylized Facts about their Determinants and Governance*

December 2008

\author{
Joshua Aizenman \\ Department of Economics \\ University of California, Santa Cruz \\ jaizen@ucsc.edu
}

\author{
Reuven Glick \\ Economic Research Department \\ Federal Reserve Bank of San Francisco \\ reuven.glick@sf.frb.org
}

\begin{abstract}
:
This paper presents statistical analysis supporting stylized facts about sovereign wealth funds (SWFs). It discusses the forces leading to the growth of SWFs, including the role of fuel exports and ongoing current account surpluses, and large hoarding of international reserves. It analyzes the degree to which measures of SWF governance and transparency compare with national norms of behavior. We provide evidence that many countries with SWFs are characterized by effective governance, but weak democratic institutions, as compared to other nonindustrial countries. We also present a model with which we compare the optimal degree of diversification abroad by a central bank versus that of a sovereign wealth fund. We show that if the central bank manages its foreign assets with the objective of reducing the probability of sudden stops, it will place a high weight on the downside risk of holding risky assets abroad and will tend to hold primarily safe foreign assets. In contrast, if the sovereign wealth fund, acting on behalf of the Treasury, maximizes the expected utility of a representative domestic agent, it will opt for relatively greater holding of more risky foreign assets. We discuss how the degree of a country's transparency may affect the size of the foreign asset base entrusted to a wealth fund's management, and show that, for relatively low levels of public foreign assets, assigning portfolio management independence to the central bank may be advantageous. However, for a large enough foreign asset base, the opportunity cost associated with the limited portfolio diversification of the central bank induces authorities to establish a wealth fund in pursuit of higher returns.
\end{abstract}

JEL Classification: E52, E58, F15, F30

Keywords: Sovereign wealth funds, capital flows, foreign exchange reserves, financial markets, governance.

*A previous draft of this paper was presented at the conference on "Sovereign Wealth Funds in an Evolving Global Financial System" sponsored by the Australia National University Centre for Applied Macroeconomic Analysis, together with the Lowy Institute for International Policy, in Sydney, September 25-26, 2008. We thank Prasanna Gai for comments and Andrew Cohn for research assistance. The views expressed below do not represent those of the Federal Reserve Bank of San Francisco or the Board of Governors of the Federal Reserve System. 


\section{Introduction}

Sovereign wealth funds (SWFs) are saving funds controlled by sovereign governments that hold and manage foreign assets. Private analysts put current sovereign wealth fund assets in the range of $\$ 2$ to 3 trillion or even higher. ${ }^{1}$ This amount is projected to grow to as much as $\$ 13$ trillion in the next ten years, an amount larger than the current global stock of foreign reserves of about $\$ 6$ trillion. ${ }^{2}$ While not a new phenomenon, the recent activities and projected growth of SWFs have stirred debate about the extent to which their size may allow them to affect financial markets and their policies may be driven by non-economic considerations.

As an increasing share of the foreign asset holdings of SWFs shift from government debt obligations to private equities, concerns also have arisen about how institutions in the "investing" and "receiving" countries may need to adapt. Much discussion has been devoted to the need for individual SWFs to be more transparent about their investment approach, by providing more information on the type and amounts of assets they hold, and about their governance structure, by clarifying how decisions are made and monitored.

This paper gives an overview of the ongoing debate about the expanding role of SWFs in international financial markets. It discusses the forces leading to the growth of SWFs and provides statistical analysis supporting stylized facts about their determinants. It also analyzes the degree to which measures of the governance and transparency of individual SWFs compare

\footnotetext{
${ }^{1}$ Ziemba (2008) estimates SWF assets amounted to around \$2 trillion at the end of 2007. Lyons (2007) and Jen (2007) give figures of roughly $\$ 2.2$ and $\$ 2.5$ trillion, respecitvely. Truman (2008) estimates that SWFs managed just under \$3 trillion at the end of 2007 (he also identifies another \$2.3 billion under management by sovereign pension funds). Definitional issues tend to account for most of the divergence in estimates. For example, Truman includes investment funds managed by monetary authorities in Saudi Arabia, Hong Kong, and Russia. Ziemba excludes these funds as well as SWFs who primarily hold domestic assets (e.g., Singapore's Temasek and Malaysia's Khazanah Fund). Based on public ownership asset data, Balding (2008) suggests that sovereign wealth funds manage much less than any of the numbers above; however, he ignores assets handled by external fund managers. ${ }^{2}$ Jen (2007) projects global SWF assets will total \$12 trillion in 2015; the IMF Survey (March 4, 2008) projects an increase to \$8-13 trillion by 2013. Lyons (2007) projects a total of $\$ 13$ trillion by 2017.
} 
with national and global norms of behavior. In addition, the paper discusses how expansion of asset holdings of SWFs may affect the level of official reserve holdings. The paper concludes with discussion of the implications of growing SWFs for international financial markets.

\section{Reasons for the Growth of SWFs}

SWFs have become an important class of investors in terms of the size of assets under sovereign control. How do they compare to other pools of global investment? As shown in Figure 1, SWF asset holdings now amount to much less than the funds under management by mutual funds, pension funds, insurance companies, \$20-30 trillion each, and less than the \$6 trillion in central bank foreign reserve holdings (including $\$ 1.8$ trillion by China). But they are more than the $\$ 1.9$ trillion under management by hedge funds and almost $\$ 1$ trillion by private equity groups.

SWFS generally fall into two categories according to the source of their foreign exchange assets. Commodity SWFs are funded by commodity exports, either owned or taxed by government (e.g. the Gulf States, Norway, Russia). They have been established for various purposes, including stabilization of fiscal revenues, management of inter-generational savings, and sterilization of the effects of balance of payments inflows on domestic inflation. Noncommodity SWFs are funded typically by the transfer of assets from official foreign exchange reserves (e.g. China, other Asia countries). Current estimates suggest that funds derived from oil and gas export revenues account for some two thirds of the total assets held by SWFs, with the rest consisting of funds mainly controlled by Asian surplus exporters.

The growth of SWFs may be viewed as a consequence of countries running persistent current account surpluses and accumulating net foreign assets. SWFs arise as a by-product of 
these current account surpluses in circumstances where sovereign governments choose to retain control of the foreign assets acquired.

There are several reasons for the accumulation of net foreign assets by sovereigns and the resulting growth of sovereign wealth funds. First, the recent commodity price boom has swelled the sovereign asset holdings of commodity-exporting countries where the public sector controls commodity exports or heavily taxes the revenues earned by private commodity exporters. Earlier commodity price booms vividly illustrate the adverse effect on competitiveness of domestic inflation and large real appreciations induced by using these windfall gains for domestic expenditures, particularly when the gains are transitory. For example, the windfall gains associated with the sharp rise in the price of oil in 1973-1974 induced oil-exporting countries to increase government spending; this spending fell sharply when oil prices collapsed in the early 1980s. Consequently, some sovereigns have sought to deal with these concerns by saving a share of the gains in SWFs. In some cases these savings are used as a financial stabilizer if commodity prices fall and depress tax revenue declines. In other cases, SWFs serve as mechanisms to transform concentrated exposure of public assets to volatile commodity prices into a more balanced and diversified global exposure, thereby protecting the income of future generations. A second factor behind the growth of SWFs is the effort by many emerging market countries to accumulate large stockpiles of international reserves by running persistent current account surpluses (see Aizenman 2007). Many of these countries, particularly in Asia, now hold more reserves than needed for prudential reasons. Attempts to diversify these reserves into potentially higher-yielding assets entail transferring them from the control of the central bank to the Treasury or to quasi-public entities, such as SWFs, with the mandate to pursue financial strategies aiming at higher long-run returns. For example, China recently set up the China 
Investment Corporation with assets worth $\$ 200$ billion to manage more aggressively a portion of its over \$1.8 trillion in foreign reserves (as of June 2008).

Of course, by definition, the global sum of all current accounts adds up to zero. Hence, the growing current account surpluses of commodity exporters and Asian countries are the mirror image of the growing current account deficits of other countries, primarily the U.S. in recent years. In this view the excess saving and accumulation of foreign assets by surplus countries is the counterpart to the excess demand and issuance of foreign liabilities by deficit countries. The resulting international wealth transfer from debtors in one country to creditors in others fosters the growth of SWFs when sovereign governments choose to retain control of the foreign assets accumulated.

SWFs are fundamentally different from monetary authorities holding official foreign reserves, where liquidity and security issues necessitate a short investment horizon and low risk tolerance. Central banks generally invest their foreign exchange reserves conservatively in safe and marketable instruments that are readily available to monetary authorities to meet balance of payments needs. In contrast, SWFs typically seek to diversify foreign exchange assets and earn a higher return by investing in a broader range of asset classes, including longer-term government bonds, agency and asset-backed securities, corporate bonds, equities, commodities, real estate, derivatives, and foreign direct investment.

SWFs typically make little use of leverage, in contrast to hedge funds and private equity funds which generally engage in highly leveraged transactions. SWFs also differ from large institutional private investors such as mutual and insurance funds, in that although they hold assets, they generally have no specific liabilities to be paid to shareholders or policyholders. SWFs similarly differ from sovereign pension funds (SPFs) in that the latter, while government- 
owned, have explicit liabilities, such as worker pensions. For this reason, SWFs typically have had less incentive to be transparent about their investment and management practices. However, as SWFs invest more of their assets in private financial markets, greater concern has arisen as to the extent to which they should follow the practices of private institutional investors.

In the appendix we present a model with which we compare the optimal degree of diversification abroad by a central bank versus that of a sovereign wealth fund, depending on the authorities' utility function. We show that if the central bank manages its foreign assets with the objective of reducing the probability of sudden stops, it will place a high weight on the downside risk of holding risky assets abroad and will tend to hold primarily safe foreign assets. In contrast, if a sovereign wealth fund, acting on behalf of the Treasury,, maximizes the expected utility of a representative domestic agent, it will opt for greater diversification towards holding more risky foreign assets. ${ }^{3}$

Our model suggests that, for relatively low levels of public foreign assets, assigning portfolio management independence to the central bank may advantageous. However, for a large enough foreign asset base accumulated through commodity exports or foreign exchange intervention, the opportunity cost associated with the limited portfolio diversification of the central bank becomes high enough to induce the authorities to establish a wealth fund in pursuit of greater returns. In these circumstances, the fund would opt for much greater investment in foreign equities, while the central bank manages its assets with limited diversification, so as to minimize the downside risk of sudden stop crises.

\footnotetext{
${ }^{3}$ We also formulate a more elaborate model of joint decision making in which we treat the Treasury as the dominant player and assume that it sets the total level of foreign assets managed by the central bank, but delegates to the central bank the responsibility for maintaining financial stability through the composition of its portfolio. Conditional on the actions of the central bank, the Treasury decides what level of public foreign assets to entrust to the central bank for management as well as the composition of the residual share of the country's public foreign assets managed through the SWF. In these circumstances, we find that the assignment of the objective to financial stability to the central bank tends to increase the gap between the optimal diversification patterns of the bank and the fund.
} 


\section{Data Analysis and Stylized Facts about SWFs}

In this section we provide graphical and statistical support for stylized facts about SWFs. Table 1 summarizes data on SWFs by country, taken from Truman (2008), including the country fund name, date of establishment, and estimated size. ${ }^{4}$ (When there is a range of size figures we take the average; when there is more than one fund per country, we take the sum and use the establishment date of the largest fund.) We exclude sovereign pension funds (SPFs), e.g., the Australia Future Fund and Canada Pension Fund, since typically they have limited foreign investment assets ${ }^{5}$ and, as noted earlier, they differ significantly in their governance structure because of the nature of the liabilities on their balance sheets. ${ }^{6}$ We also exclude non-Federal sovereign wealth funds, e.g. the Alaska Permanent Fund and the Alberta Heritage Savings Trust, since we wish to focus on cross-country differences in SWF behavior at the national level.

Figure 2 depicts the SWFs in our sample by decreasing total asset size. Observe that SWF asset holdings are fairly concentrated, with the top six funds, accounting for three-fourths of total SWF assets. The United Arab Emirates, including the Abu Dhabi Investment Authority, established back in 1976, and other assorted funds, have a combined asset value of over \$800 billion. Norway’s Government Pension Fund - Global (previously called the Petroleum Fund of Norway) was established in 1990 and now holds over \$350 billion. In Asia, Singapore’s two government investment funds - the Government Investment Corporation (GIC) and Temasekhave combined assets of over $\$ 300$ billion. Saudi Arabia’s oil surplus funds, mainly managed by the central bank together with its reserves, amount to almost $\$ 300$ billion. Kuwait and China

\footnotetext{
${ }^{4}$ We used 2003 as the establishment date of the Qatar Investment Authority, rather than Truman's 2005 date, based on information from the fund's website.

${ }^{5}$ Some SWFs do not hold foreign assets exclusively. For example, Singapore’s Temask and Malaysia's Khazanah Fund hold substantial domestic assets, as indicated in Figure 2.

${ }^{6}$ We will compare the governance behavior of SWFs and SPFs below.
} 
hold roughly $\$ 200$ billion each in SWFs. As shown in Table 1, almost all of these large funds have been in existence for fairly long periods, having been established in 1990 or earlier (China is the exception).

\section{A. Determinants of SWFs}

We begin with simple depictions of the characteristics of countries with SWFs relative to other countries. All data are taken from the World Bank’s World Development Indicators, 2008; we use the data for 2006, the latest reported in the WDI, or the most recent available. Small countries with populations in 2006 of less than 250,000 are excluded.

Figure 3 depicts the distribution of countries according to their specialization in fuel exports, defined as fuel exports as a share of total merchandise exports. Countries with SWFs in 2007 or 2008 are indicated by dark (blue) bars. Not surprisingly, the figure shows that SWFs tend to be prevalent among intensive fuel-exporting countries. As fuel prices have risen over time in recent years, countries that are heavy fuel exporters have earned sizable amounts of revenue from exports and accumulated foreign assets. ${ }^{7}$ They also have had more reason than other countries to diversify their foreign asset holdings through SWFs.

Figure 4 depicts the distribution of SWFs across countries ranked by average current account surpluses as a share of GDP over the period 2002-2006. (In cases where current account data is missing, we use the most recent years or use trade balance data instead.) Observe that countries with SWFs tend to be countries with high current account surpluses. Although many SWF countries with large current account surpluses also are intensive fuel exporters (the raw correlation is 0.48 , the rank correlation is .37), many are not. Comparison of Figures 2 and 3

\footnotetext{
${ }^{7}$ This presumes that imports expand by less than exports.
} 
indicates that economies, such as Hong Kong, China, and Chile, among others, rank low in terms of fuel exports, but relatively high in terms of current account surpluses.

Figure 5 depicts the distribution of SWFs across countries ranked by GDP per capita (in \$2000). Observe that countries with SWFs tend to be fairly evenly distributed across income levels. That is, there are high, medium, and low income countries with SWFs.

What are the foreign reserve holdings of countries with a SWF? Figure 6 shows the distribution of countries ordered by their level of foreign reserves (excluding gold) as a share of GDP. Not surprisingly, the ratio of reserves to GDP is relatively high in many countries with SWFs, particularly in countries that have recently established such funds. However, reserves are somewhat lower in some countries, particularly those in the Gulf area (e.g. Saudi Arabia, Kuwait, Oman, United Arab Emirates) with SWFs of longer duration.

We now turn to more formal statistical analysis of the determinants of sovereign wealth funds. We first analyze the effect of individual country characteristics on the existence of a sovereign wealth fund in 2007 or 2008 . Table 2 reports the results of probit regressions of the incidence of SWFs, defined as a 0-1 dummy, as a function of the (five-year average) current account/GDP ratio, fuel exports as a share of total exports, and ore and metal exports as a share of total exports. As reported in column (1), the coefficients on the first two variables are positive and significant. Countries that run larger current account surpluses or that specialize in fuel exports are more likely to have established sovereign wealth funds. This confirms the insights drawn from Figures 3 and 4.

In terms of economic significance, an increase in a country's current account surplus as a percent of GDP by 10\% percentage points (as occurred in China between 2001 and $2007^{8}$ ) raises

\footnotetext{
${ }^{8}$ China's current account balance as a ratio to GDP rose from 1.3\% in 2001 to $11.1 \%$ in 2007 (IMF World Economic Outlook, April 2008, Statistical Appendix, Table A12.)
} 
the likelihood of a SWF by 8 percentage points $(0.767 \times 100)$. A 10 percentage point increase in fuel exports as a share of total merchandise exports by $10 \%$ raises the probability by 3 percentage points. In contrast, the coefficient on ore and metals exports, though positive, is not significant. $^{9}$

Other possible determinants are considered in columns (5) and (6) of Table 2. The coefficient on GDP per capita is positive, but insignificant. ${ }^{10}$ The association of foreign reserves and the likelihood of a SWF is positive. We will discuss the issue of the interaction of SWF assets and reserve holdings below.

\section{B. SWFs and National Governance}

What about the role of national governance? Do countries with high or low governance tend to establish SWFs?

To answer this question, we use the Worldwide Governance Indicators constructed by Kaufmann, Kraay, and Mastruzzi (KKM, 2007) which capture key dimensions of governance for individual countries: ${ }^{11}$ These include the following six subindices:

(i) "Voice and Accountability" (VA), which measures the extent to which a country's residents participate in selecting their government, as well as engage in freedom of expression;

(ii) "Political Stability and the Absence of Violence" (PS), which measures perceptions of the likelihood that the government will be destabilized or overthrown by unconstitutional or violent means, including domestic violence and terrorism;

(iii) "Government Effectiveness" (GE), a measure of the quality of public policies and services, independence from political pressures, and the credibility of the government commitment to these policies;

\footnotetext{
${ }^{9}$ Among countries with SWFs, ores and metals comprise more than $25 \%$ of total exports only for Chile.

${ }^{10}$ Restricting the sample by omitting advanced countries results in a positive coefficient for the GDP per capita variable. Thus, among developing countries, lower income countries are less likely to establish SWFs.

${ }^{11}$ These indicators are available for the years 1996 through 2006 on the Worldwide Governance Indicators Web site (http://www.govindicators.org).
} 
(iv) "Regulatory Quality" (RQ), a measure of the ability of the government to formulate and implement sound policies that promote private sector development;

(v) Rule of Law (RL), a measure of the extent to which agents have confidence in and abide by the rules of society, including the quality of contract enforcement, the police, and the courts, as well as the likelihood of crime and violence; and

(vi) Control of Corruption (CC), measuring the extent to which the government limits corruption and rent seeking by elites and private interests.

These variables are constructed on a standardized scale ranging from -2.5 to 2.5 .

(The data are scaled such that a 1 unit change is equivalent to 1 standard deviation of each variable’s distribution.) Higher values indicate "better" performance. Note that the "Voice and Accountability" subindex captures the degree of development of democratic institutions. An aggregate governance score for each country is given by the average of the six subindices, which we shall refer to as the "KKM governance average."

Figure 7 shows the distribution of SWFs across countries ranked by their KKM governance average level in 2006, the latest date available. ${ }^{12}$ The chart does not indicate any obvious association between national average governance and the presence of a sovereign wealth fund. In contrast, as shown in Figure 8, SWF countries appear to rank lower on the voice and transparency measure, our indicator of democracy performance. Only 5 of 26 SWFs have democracy levels in the top quartile; most are in the bottom half of the sample.

This finding is supported by Figure 9 which compares governance performance for different country groupings - countries with SWFs, other developing countries, and industrial countries. ${ }^{13}$ It is apparent that countries with SWFs score significantly lower than do industrial countries for all governance measures, including the average as well as the subindices. However, in comparison with other developing countries, countries with SWFs score somewhat higher,

\footnotetext{
${ }^{12}$ We still exclude countries with populations of less than 250,000.

${ }^{13}$ All figures are unweighted averages of the countries in each grouping. The industrial countries group excludes Norway which is included in the SWF group.
} 
with the notable exception of voice and accountability where they score much lower. Thus, while SWF countries display somewhat better governance on average than other developing countries, they are characterized by relatively low democracy performance.

Table 3 reports the results of univariate probits involving our national governance measures. Column (1) of the table confirms the absence of any statistical association between national governance and SWF likelihood with our country sample. The other columns of Table 3 report the effects of the individual governance subindices. Observe that none are significant, with the notable exception of the voice and accountability index which has a negative as well as significant effect on the incidence of SWFs. This confirms the observation drawn from Figures 7 and 8 that countries with more (less) democratic political institutions are less (more) likely to have SWFs. ${ }^{14}$

Table 4 restricts the sample to developing countries only (with the exception of Norway which is included in the sample because it has a SWF). Now we find that the governance average and most of the other subindices have significantly positive effects on SWF likelihood. ${ }^{15}$ However, the effect of voice and accountability though still negative, is no longer significant. This supports the fact that developing countries with better governance, particularly in terms of government effectiveness, regulatory quality, and control of corruption, are more likely to have SWFs.

\section{C. SWFs and Individual Fund Governance}

\footnotetext{
${ }^{14}$ If industrial countries are excluded from the sample, then the KKM and its subindices are generally positive and significant. The coefficient on VA is still negative, but no longer significant.

${ }^{15}$ Multivariate probits, with controls for whether a country has current account surpluses or is a fuel or ore\&metal exporter, yield similar results for both the full and developing country only samples.
} 
Thus far we have examined the association of national governance characteristics with the incidence of SWFs across countries. What about the governance characteristics of individual SWFs?

SWFs differ in their strategies for investing abroad and in the information they provide about their activities. The Norwegian Government Pension Fund, the most transparent large SWF, invests in a wide set of foreign industrial and emerging market securities, with significant portions under external management. It generally has not sought out management control of its investments, tending to have only small ownership shares in companies. Temasek, the Singapore government's strategic investment arm, was established in 1974. It takes long-term stakes in local and foreign companies and tends to take a more activist approach to its investments. Temasek has released some information about its financial performance since 2004, but the available information has been confined to consolidated accounts that do not disclose flows between subsidiary investments and omits historical financial data before 2001. Other sovereign funds have been more opaque.

The degree of transparency displayed by a SWF at home and abroad has implications for the extent and nature of its activities. In more democratic countries, political contestability implies that the SWF agenda and investment goals should be more aligned with the domestic electorate, implying greater demand for domestic transparency. In these circumstances, greater domestic transparency may increase the electorate's support for the SWF, thereby expanding the resources delegated to it. In less democratic countries, SWF management may reflect the preferences of a narrow power group, and the determination of internal transparency is more involved. Too little transparency may backfire by fueling popular dissent, encouraging political instability, and possibly reducing the tenure of the government and its management team by its 
forceful removal from office. Yet, "high” domestic transparency may entail another cost to the government in the form of greater discontent, inducing other power groups to challenge the size and the mandate of the SWF. In these circumstances, greater transparency may lessen the reported foreign assets allocated to SWF for management. In the appendix model we discuss how the degree of a country's transparency may affect the size of the foreign asset base entrusted to a SWF's management.

A SWF also may face a complex trade off regarding the degree of international transparency it displays, i.e. the degree to which its investment strategy and holdings are transparent to the global financial system. On the one hand, if the SWF benefits from access to superior talent and information, greater transparency may reduce the effectiveness of any proprietary strategy used by the fund. On the other hand, inadequate international transparency tends to reduce the hospitality shown towards foreign direct and portfolio investment in the host country and possibly encourage local efforts to reduce a SWF's access to profitable business opportunities. ${ }^{16}$

To provide empirical content to the role of governance in the activities of SWFs, we next examine the governance characteristics of the individual SWFs in our sample described in Table 1. We first explore the question as to how the governance of individual SWFs compares with the KKM national governance measures. To do so we make use of Truman (2008) governance scores for nonpension sovereign wealth funds. ${ }^{17}$ He constructs 4 subindices measuring the behavior of individual SWFs in various dimensions:

\footnotetext{
${ }^{16}$ These considerations suggest that the degree of transparency displayed by a SWF may be determined endogenously in an effort to maximize foreign investment opportunities. We allude to this possibility in the appendix, but do not model it.

${ }^{17}$ Truman also collects governance data for ten sovereign pension funds. We will compare the results for sovereign wealth and sovereign pension funds below.
} 
(i) "Fund Accountability and Transparency," which measures the clarity of investment strategy, investment activities, reporting, and audits;

(ii) "Fund Structure," measuring clarity of the fund's basic structure, including its objectives, fiscal treatment, and independence from management of the country's international reserves;

(iii) "Fund Behavior," measuring the fund's approach to managing its portfolio and using leverage and derivatives.

(iv) "Fund Management," which measures the existence of investment guidelines and the role of the government and SWF managers in executing them. ${ }^{18}$

Higher values of "Fund Transparency" represent increased SWF accountability and transparency. Higher values of "Fund Structure" correspond to clearer guidelines for the structure and scope of SWF activities. Higher values of "Fund Management" imply more disclosure about the governance environment. Higher values of "Fund Behavior" indicate that the SWF utilizes more advanced investment and risk management strategies. In addition, Truman reports a total score for each SWF, constructed as the sum of the individual index scores. We interpret an individual fund's total score as a measure of the quality of its overall governance. It should be noted that the 4 subindices are not weighted equally in constructing the total score; "Fund Accountability and Transparency" accounts for almost half of the total, implying that variations across funds in their total governance score primarily reflect differences in accountability and transparency. ${ }^{19}$

Table 5 reports the correlations of KKM national governance measures and the Truman governance measures for the SWFs in our sample. For countries with more than one SWF we use

\footnotetext{
${ }^{18}$ We have changed Truman's actual label for this subindex from "governance” to "management” in order to avoid confusion when referring to Truman's total score as a measure of overall governance.

${ }^{19}$ The maximum number of points in the four categories are 14, 8, 6, and 5, respectively, giving an overall score maximum of 33. Hence transparency accounts for $42(=14 / 33)$ percent of the total score.
} 
the scores for the SWF fund with the largest amount of assets. There is no score data on SWFs in Saudi Arabia, Gabon, and Libya, as indicated in Table 1, leaving 26 SWF observations. ${ }^{20}$

Observe from Table 5 that the KKM governance average and the Truman total score measures are positively, but weakly, correlated (the correlation coefficient is 0.28 ; the p value is 0.16). The top row of the table reveals that almost all of this correlation is attributable to the voice and accountable variable, which is strongly correlated with the Truman total score (the coefficient is 0.56 ; the p value is 0.00 ) as well as with the Truman subindices. Thus countries with high (low) national democracy ratings tend to have sovereign wealth funds with high (low) Truman governance scores as well. In particular, countries with more democratic institutions also tend to have SWFs that display more accountability and transparency.

The scatter plots in Figures 10 and 11 give further insight. Figure 10 plots the KKM average national governance measure against Truman's total SWF governance score for each SWF. First, observe that there is a relatively wide dispersion in the Truman fund governance scores plotted on the horizontal axis. SWFs in Norway, Hong Kong, Chile as well as in Khazakistan, Azerbaijan, and Timur-Leste all score high in terms of the Truman total score measure, implying relatively effective governance and transparency. At the other end of the scale are the SWFs in the oil-producing countries of United Arab Emirates, Qatar, Brunei, and Oman, as well as in Sudan, Venezuela, Iran, and Nigeria.

Second, observe that the scatter plot and fitted regression line suggest a weak positive correlation between the KKM and Truman measures. This is consistent with the correlation results in Table 5: countries characterized by better governance tend to have SWFs displaying better overall governance. The weakness of the correlation appears attributable to the outlier

\footnotetext{
${ }^{20}$ For the SWFs in Truman's full sample the total score averages 15.1 for SWFs; for our sample of 26 countries, which uses only the scores for the largest SWF in each country, the average is 19.1 Truman's average for 10 SPFs is 29.2. For his full sample of $33 \mathrm{SWFs}$ and $10 \mathrm{SPFs}$ pooled together the average is 18.3.
} 
observations in the upper left quadrant - the "older" fuel-producing countries of the United arab Emirates, Qatar, Brunei, Oman - and the outlying observations in the lower right quadrant - the “newer” fuel-producing states of Russia, Khazakistan, Azerbaijan, and Timur-Leste. The first set of countries have relatively high KKM governance scores and low Truman fund scores, while the second set have relatively low KKM governance scores and high Truman fund scores.

Figure 11 gives additional insight with a scatter plot of the KKM voice and accountability subindex vs. Truman's total SWF score. Here we see that the oil- producing countries of the UAE, Qatar, Brunei, and Oman have relatively low democracy levels (as indicated by the downward pointing arrow). Thus despite relatively high overall KKM governance levels, the "older" fuel producing countries have relatively low democracy scores as well as SWFs with low Truman fund governance scores, particularly in terms of transparency and accountability. In contrast, the SWFs of the newer fuel-producing countries - Russia, Khazakistan, Azerbaijan, and Timur-Leste, - who also have low democracy scores, have higher Truman fund scores, i.e. they are more transparent than the sovereign funds in the older oil-producing countries. Why might this be so? One possible explanation is that countries that have only recently begun to develop their fuel resources have a greater incentive to foster more global integration by establishing institutions, such as SWFs, with more transparency and accountability. It is easier to change the level of transparency of a fund than to change a country's political system.

Some have suggested that sovereign funds may face more issues when investing abroad the greater the extent to which the practices of their SWFs diverge from those of domestic institutions managing public funds in the recipient countries.

Further insight can be obtained from Figures 12 and 13 which present the Truman and KKM measures for different SWF country groupings - "old" oil-exporting countries with 
SWFs, ${ }^{21}$ Norway, and other SWFs. For comparison, we also report results for 10 sovereign pension funds (SPFs) in industrial countries (as well as the sub-national SWFs in the U.S. and Canada), using data from Truman (2008) ${ }^{22}$ The Truman subindices are normalized to reflect the percent fraction (up to 100) of the maximum score possible for each subindex.

Figure 12 shows that the older oil-exporting countries have lower Truman fund governance scores, primarily because of limited transparency and accountability, in comparison to other SWF countries. All are well below the standards of sovereign pension funds as well as Norway’s SWF. Figure 13 shows that the older-exporting countries generally have better KKM governance levels than those of other SWFS (except Norway, of course), but lower democracy levels. These figures illustrate how the practices of many large existing sovereign funds, particularly those originating in less democratic countries, differ from the practices of pension funds as well as Norway's government fund. Clearly, there is still a great difference between the governance standards of the economies in which SWFs have been established and the governance standards of the industrial economies in which they are seeking to invest.

\section{D. Determinants of SWF Asset Size}

As shown in Figure 2, SWFs vary greatly in asset size. What explains the size differences of SWFs? Funds established a long time ago presumably have had more time to accumulate assets. Increasing oil prices and oil export revenues contribute to national asset accumulation over time as well.

The bar chart in Figure 14 illustrates this by depicting SWF asset holdings (and foreign reserves) as a share of GDP, ranked by the duration of the fund (defined as the number of years

\footnotetext{
${ }^{21}$ This grouping consists of the Gulf countries - Oman, Qatar, Kuwait, Saudi Arabia, United Arab Emirates - and Brunei (Saudi Arabia is excluded from the Truman scores because of the lack of data on this measure).

${ }^{22}$ The SPF sample also includes China's National Social Security Fund. Omitting this SPF does not affect the results.
} 
between 2008 and the fund's establishment date, given in Table 1). Observe that the largest funds are those who are the oldest - Saudi Arabia, Kuwait, United Arab Emirates, Oman, Singapore, and Brunei. (Qatar, whose SWF was established more recently - in 2003 - is an outlier.)

Tables 6 and 7 confirm these findings with cross-section regressions of SWF asset size relative to GDP for the sample of 26 countries with SWFs (excluding Kiribati, Sao Tome, and Timur-Leste because of lack of data). We include fuel exports as a share of GDP as well as fund duration as explanatory variables

Columns (1) and (2) of Table 6 show that the size of a country's SWF is greater the higher the country's fuel export revenue and the longer the fund's duration. These effects are significant at the $10 \%$ level or better. The remaining columns of Table 6 report the effect of Truman fund scores on asset size. Controlling for oil and duration, lower Truman fund governance scores appear to be associated with higher fund size (though only the effect of "Structure" is significant, at $10 \%) .{ }^{23}$ These results provide somewhat weak evidence that the less transparent SWFs are relatively large in size.

Table 7 reports the effects of the KKM national governance measures on SWF size, controlling or oil revenue and duration. Here we find that that better national governance is associated with larger fund size, with the notable exception of the "voice and accountability" measure which is negative (though not significant). ${ }^{24}$ This is consistent with earlier findings concerning the likelihood of a country having a SWF. Countries for which oil revenue plays less of a role in explaining the accumulation of SWF foreign assets tend to have better governance as well as more democratic institutions, compared to other developing countries. Conversely,

\footnotetext{
${ }^{23}$ The same general results are obtained with univariate regressions without the oil or duration variables.

${ }^{24}$ With controls for oil or duration, the governance variables are still positive, but insignificant.
} 
countries for which oil revenue plays more of a role, particularly “older” oil exporters, appear to be characterized by higher levels of governance in terms of government, regulatory, and legal effectiveness, but relatively less democratic institutions.

The result that the largest funds appear to be characterized by relatively low standards of transparency and accountability is part of the basis for why these funds have encountered concerns when seeking to expand their presence in foreign financial markets.

\section{E. SWF Assets and Foreign Reserves}

As countries choose to entrust more of their sovereign wealth to investment funds it is expected to affect official reserve accumulation, with funds likely shifting away from reserves held by the central bank. Is there any evidence of such a shift?

Figure 14 plots the ratio of SWF assets (as of end 2007) and of foreign reserves to GDP (as of 2006) in the order of decreasing fund duration. ${ }^{25}$ Observe that the older SWFs not only have relatively high SWF asset /GDP ratios, they also have relatively low reserve/GDP ratios as compared to the more newly established SWFs (with the exception of Qatar). Figure 15 supports this observation by plotting the ratio of SWF assets to reserve assets. ${ }^{26}$

To examine the interaction of SWF assets and reserves more formally, we report results of a panel regression of the determinants of foreign reserves relative to GDP over the period 1985 to 2006. The explanatory variables include reserve volatility (measured by the standard deviation of reserve holding changes over five years), the ratio of imports to GDP, the ratio of

\footnotetext{
${ }^{25}$ There are no reserve data for Iran, Kiribati, and Sao Tome. These countries are excluded from Figure 14.

${ }^{26}$ Ziemba (2008) reports that the official reserves of GCC countries (excluding Saudi Arabia), Saudi Arabia, and Kuwait were roughly $\$ 100$ billion, $\$ 30$ billion, and $\$ 17$ billion, respectively in early 2008. These figures are well below reserve holdings of the central banks in the region.
} 
M2 to reserves, and the occurrence of currency crises. ${ }^{27}$. Because of data limitations the panel includes only 22 countries with a SWF.

Table 8 reports random effects estimates of the panel with a set of year dummies and error clustering at the country level. As shown in col. (1), reserve holdings rise with the import/GDP and M2/reserve ratios. These effects are as expected: reserve holdings should be higher the greater the need to cover the costs of imports and the greater the vulnerability to liquidity crisis associated with higher short-term domestic currency liabilities of the banking system relative to reserve holdings. Reserve holdings decline with the occurence of a currency crisis. The effect of reserve volatility is insignificant.

Column (1) also includes a 0-1 dummy variable - "SWF present" which has a value of 1 for those years in which a country has a SWF. ${ }^{28}$ The coefficient on this variable is positive and significant, indicating that the presence of SWF raises the level of reserve holdings. ${ }^{29}$ This does not support the view that establishment of a SWF leads to lower official reserve levels over time. One possible reason is that most of the SWFs in the sample have been established relatively recently, leaving insufficient time for effects on the level of central bank reserve holdings to occur.

Column (2) of Table 8 adds an additional dummy variable -- SWF “older” oil exporter -which has a value of 1 only for those countries which had SWFs in place before 1990 that were also significant oil exporters. Here we find that negative coefficient. This implies that, relative to all SWF countries, oil-exporting countries with SWFs of long duration, hold lower levels of

\footnotetext{
${ }^{27}$ We thank Yin-Wong Cheung and Hiro Ito for providing the data for some of these variables; see Cheung and Ito (2007) on currency crises. We also considered the use of a measure of the opportunity costs to holding reserves (defined as the domestic lending rate minus the U.S. Treasury bill rate), but the absence of a domestic interest rate for many of the SWF countries in our sample, lead us to omit it.

${ }^{28}$ The value of this dummy is set equal to 1 in 2006 for any country which established a SWF in 2007 or 2008.

${ }^{29}$ Ideally, we would prefer to be able to utilize time-varying data for SWF assets. Unfortunately we only have the single data point for SWF assets of year end 2007.
} 
reserves. This is consistent with the view that over time countries with SWFs will tend to hold relatively less reserves.

In an Appendix we compares the optimal patterns of portfolio diversification managed by a central bank and a sovereign wealth fund, possibly acting as an agent for the Treasury.

We first present a simple model with which we compare the optimal degree of diversification depending on the authorities' utility function. We assume that the objective of the bank is to maintain financial stability by solely focusing on the objective of reducing the probability of sudden stops. ${ }^{30}$ In contrast, we presume that the Treasury, acting through a SWF, maximizes the expected utility of a representative domestic agent In this framework we show that the central banks's focus on financial stability implies that it will place a higher weight on the downside risk of sudden stops than will the SWF. Consequently, the bank tends to bias its portfolio strategy towards holding more of the safe asset, whereas the SWF opts for greater diversification towards risky foreign assets. We also show how the diversification gap between the strategies of the bank and SWF is affected by various parameters of the economy, such as the volatility of equity returns.

We follow with a more elaborate model of joint decision making in which we treat the Treasury as the dominant player and assume that it sets the total level of foreign assets managed by the central bank, but delegates to the central bank the responsibility for maintaining financial stability through the composition of its portfolio. Conditional on the actions of the central bank, the Treasury decides what level of public foreign assets to entrust to the central bank for management as well as the composition of the residual share of the country's public foreign

\footnotetext{
${ }^{30}$ We abstract from other possible central bank objectives, such targeting inflation under flexible exchange rate regime. We also do not model deeper reasons for our assignment of objectives, such as a possible bias towards nominating a conservative central bank governor with a narrower policy focus than the representative agent (see Rogoff, 1985; Walsh, 1995; Obstfeld, 1996; and Aizenman and Glick, 2008).
} 
assets managed through the SWF. In these circumstances, we find that the assignment of the objective to financial stability to the central bank tends to increase the gap between the optimal diversification patterns of the bank and the SWF.

We also discuss how the degree of a country's internal and external transparency affects the country's foreign asset returns and management.

\section{Implications of SWFs for Global Financial Markets}

There have been growing concerns about how the size and composition of SWF portfolios may affect global financial markets. On the one hand, SWFs are viewed as institutions with relatively long investment horizons, generally operating with little leverage, thus providing a stable source of cross-border liquidity for the global financial system. In fact, Kotter and Lel (2008) show that SWF acquisition announcements raise the returns of target firms, particularly if they are relatively transparent. ${ }^{31}$ This finding suggests that investors use voluntary SWF disclosure as a signal of the quality of screening and monitoring by SWFs about investment opportunities.

Moreover, during the recent 2007-08 global financial crisis SWFs have been a source of new capital to foreign banks and investment firms, particularly in the United States. Between November 2007 and January 2008, SWFs from emerging markets injected more than \$44 billion of capital into needy financial institutions in advance economies; these investments accounted for roughly $3 / 4$ of the total capital raised by target companies over period (FRBNY). In general, they have been structured to keep individual investors' ownership stakes below the 5 or $10 \%$ limits that would invite closer regulatory attention.

\footnotetext{
${ }^{31}$ Specifically, they show that SWF acquisition announcements raise the risk-adjusted returns of target firms by 2.1 percent on average, and by $3.5 \%$ if they implement independent audits or make annual reports publicly available.
} 
On the other hand, there are concerns reflecting the view that the growing size of SWFs matters and that sovereign fund management may be motivated by non-economic considerations, deviating from conventional wealth maximization. Apprehension about the size effect of funds, both private and public, is not new, reflecting the possibility that large funds may use their market power strategically, potentially leading to greater financial instability. An example of these concerns is the alleged role of large private hedge funds in coordinating speculative attacks on the British pound and other currencies participating in the European exchange rate mechanism in the early 1990s. The extra dimension added by SWFs is the possibility that sovereign investors may use their strategic leverage for narrow nationalistic objectives (Summers 2007, Kimmitt 2008). The concern is that financial globalization has reached the point where the sheer size of foreign savings may distort sovereigns' incentives, shifting them from beneficial diversification toward zero-sum game policies. These may include supporting domestic "national champion” firms, buying controlling positions in foreign firms with proprietary knowledge, or increasing control of financial and tangible infrastructure abroad (telecommunication, energy, ports, etc.).

Such developments may also lead to the proliferation of capital controls and financial protectionism, ultimately risking international trade in goods and services. Already, globalization, despite its benefits, has raised sensitivities around the world. In particular, there is rising opposition in many countries to the control or major stakes that state-controlled SWFs are taking in foreign private companies. The adverse political reaction to efforts by China's state owned oil enterprise CNOOC to acquire the U.S. oil firm Unocal in 2005 and by the United Arab Emirates' DP World to acquire several major U.S. ports are well known. More recent financial investments, such as Abu Dhabi Investment Authority's investment in Citigroup, have prompted 
less concern, in part because of assurances that no control or active management of the target firm would be sought. Emerging markets also at times have expressed sensitivity to certain investments by other emerging markets. Temasek’s purchase of a controlling stake in the Thai telecom firm Shin Corp. from the family of then-Prime Minister Thaksin Shinawatra in January 2006 sparked off a political crisis in Thailand.

As a result of these concerns, a range of policies have been proposed. Some observers call for imposing stringent transparency requirements on SWFs, well above the present requirements on private financial funds (Truman 2007). In this connection, the U.S. Treasury has suggested that the International Monetary Fund and World Bank play an oversight role to limit the systemic risks of unregulated SWFs, including the formulation of best practice guidelines. In the Spring of 2008 twenty-five SWFs formed an international working group, facilitated by the IMF, to develop a set of voluntary best practices and guidelines (IMF 2008). A preliminary agreement was announced in early September of this year.

Others have proposed greater scrutiny of foreign government entities seeking operational control of companies in which they invest, particularly if they choose to exercise the voting rights of their equity shares. Accordingly, some have advocated that SWFs should be allowed to invest only in nonvoting equity shares (Buiter 2007). In addition, some call for restricting SWFs' operations to reciprocal arrangements, where the ability of a country to buy foreign assets would be conditioned on granting similar access to foreign funds (Economist 2007).

Further insight into this issue is gained by noting that economic theory suggests that the diversification benefits associated with increased globalization can be obtained best by buying a share of a "global fund," composed of all the traded assets of all countries. This suggests that the expanding role of SWFs may be best accommodated by their purchasing shares of a fund 
composed of the indexes of all the countries forming the global financial system. Such diversification provides the best mechanism for eliminating idiosyncratic risks. Short of engaging in potentially destabilizing zero-sum speculation, large players approaching the size of SWFs should not expect to get more than the gains associated with holding such wide "country funds."

Taking the insight provided by this benchmark seriously, a policy of encouraging SWFs to invest in well-diversified index instruments, such as the S\&P 500,Wilshire 5000, Dow Jones, Wilshire Global Total Market Index, etc., has the advantage of providing a workable solution to challenges associated with SWFs. ${ }^{32}$ The requirement for stringent transparency tests of SWFs may be unrealistic, due to costly monitoring and collection of information. Channeling the activities of SWFs into widely diversified country funds offers diversification gains to investors, while minimizing the exposure of a given country to strategic "cherry picking," that is, selectively buying control in entities due to narrow nationalistic objectives. One may also view it as a stepping stone towards deeper global diversification, as it may encourage the proliferation of country indexes in countries that are interested in gaining from financial globalization. Such a policy could be implemented either with the guidance of international financial institutions or as the outcome of bilateral negotiations between SWFs and potential recipient countries.

\section{Conclusions}

This paper presents statistical analysis supporting stylized facts about sovereign wealth funds (SWFs). Evidence is provided about the association of SWFs with a country's fuel export performance and current account surpluses. The paper also analyzes the degree to which measures of SWF governance and transparency compare with national governance standards.

\footnotetext{
32 This suggestion was first made in Aizenman and Glick (2007).
} 
We find that countries with SWFs score significantly lower than do industrial countries for various governance measures. However, in comparison with other developing countries, countries with SWF countries are characterized by somewhat higher governance standards, with the exception of voice and accountability - a measure of democratic institutional development -where they score much lower. Thus, while SWF countries display somewhat better governance on average than other developing countries, they are characterized by relatively low democracy performance, particularly in fuel-exporting countries.

It is also shown that the governance performance of individual SWFs is weakly correlated with measures of national governance. That is, SWFs funds tend to operate in accordance with national norms of governance, with the notable exception of some fuel-intensive exporting countries which are characterized by relatively low democratic performance. In particular, older SWFs established in fuel-exporting countries appear to be relatively less transparent, while newer SWFs established in fuel-exporting countries appear to be more transparent. We suggest that countries that have only recently begun to develop their fuel resources have a greater incentive to foster more global integration by establishing institutions, such as SWFs, with more transparency and accountability. It is easier to change the level of transparency of a fund than to change a country’s political system.

We also show how the practices of many large existing sovereign funds, particularly those originating in less democratic countries, differ from the practices of pension funds in industrial countries. Clearly, there is still great difference between the governance standards of the economies in which SWFs have been established and the governance standards of the economies in which they are seeking to invest. 
The evidence presented in this paper suggests that over time countries may transfer a greater share of the public sector's foreign assets from official reserves into SWFs. The ultimate impact that formation of SWFs will have on the dynamics of hoarding international foreign reserves requires more data and time to resolve.

The present global financial crisis illustrates the importance of the self insurance services provided by holding international reserves as well as the usefulness of policies that channel some share of windfall gains associated with terms of trade improvements into sovereign wealth funds (e.g., see the experience of Chile in recent years). While the recent drop in global commodity prices and equity returns may have reduced the relative appeal of SWFs, a resumption of global growth may restore their attractiveness. However, if the "great moderation" decades are indeed over and volatility in financial markets remains highs, monetary authorities may place a bigger weight on holding more reserves as a means of minimizing the expected costs of sudden stop events. 


\section{References}

Aizenman, J. (2008), "Large Hoarding of International Reserves and the Emerging Global Economic Architecture,” The Manchester School, 76: 487-503.

Aizenman, J. and R. Glick (2007), "Sovereign Wealth Funds: Stumbling Blocks or Stepping Stones to Financial Globalization? FRBSF Economic Letter, No 2007-38.

Aizenman, J. and R. Glick (2008), “Pegged Exchange Rate Regimes - A Trap?” Journal of Money, Credit and Banking, 40: 817 - 835.

Aizenman J. and J. Lee (2007), “International Reserves: Precautionary versus Mercantilist Views, Theory and Evidence,” Open Economies Review, 18:191-214.

Balding, Christopher (2008), “A Portfolio Analysis of Sovereign Wealth Funds,” University of California, Irvine, mimeo.

Buiter,W. (2007), “Taming SovereignWealth Funds in Two Easy Steps,” Maverecon Willem Buiter’s Blog, July 24. http://maverecon.blogspot.com

Cheung, Yin-Wong and Hiro Ito (2007), “A Cross-Country Empirical Analysis of International Reserves,” mimeo, University of California, Santa Cruz,

Diamond D. and P. Dybvig (1983) “Bank runs, Liquidity and dposit Insurance,” Journal of Political Economy, 91:401-419.

Economist (2007), “Fear of Foreigners,” August 14 (online only).

http://www.economist.com/business/ displaystory.cfm?story_id=9641906

Hermalin, B. and M. Weisbach (2007), “Transparency and Corporate Governance,” NBER Working Paper No. 12875

IMF (2007), Global Financial Stability Report, September.

IMF (2008a), Sovereign Wealth Funds-A Work Agenda,” February 29, 2008, available at http://www.imf.org/external/np/pp/eng/2008/022908.pdf.

IMF (2008b), "International Working Group of Sovereign Wealth Funds is Established to Facilitate Work on Voluntary Principles,” press release, May 1, 2008.

Jen, S. (2007), How Big Could Sovereign Wealth Funds Be by 2015? Morgan Stanley Global Research, May 04, 2007, available at http://www.morganstanley.com.

Johnson, S. (2007), “The Rise of Sovereign Wealth Funds,” Finance and Development, 44-3. 
Kaufmann, Daniel, Aart Kraay, and Massimo Mastruzzi (2007), “Governance Matters VI: Aggregate and Individual Governance Indicators, 1996-2006,” World Bank Working Paper WPS4280.

Kimmitt, Robert M. (2008), "Public Footprints in Private Markets: Sovereign Wealth Funds and the World Economy,” Foreign Affairs 87, no.1 (January-February): 119-30.

Kotter, Jason and Ugur Lel (2008), "Friends or Foes? The Stock Price Impact of Sovereign Wealth Fund Investments and the Price of Keeping Secrets,” Board of Governors, International Finance Discussion Papers No. 940, August.

Lyons, Gerard (2007), “State Capitalism: The Rise of Sovereign Wealth Funds,” Standard Charter, November 7.

Maslakovic, M. (2008), “Sovereign Wealth Funds 2008,” International Financial Services London, available at http://www.ifsl.org.uk.

Obstfeld, M. (1996), "Models of Currency Crises with Self Fulfilling Features.” European Economic Review 40 (April), 1037-1048.

Rogoff, K. (1985), “The Optimal Degree of Commitment to an Intermediate Monetary Target,” Quarterly Journal of Economics, 1169-1189.

Truman, E. (2007), “Sovereign Wealth Funds: The Need for Greater Transparency and Accountability,” Peterson Institute for International Economics, Policy Brief No. PB07-6, Washington DC.

Truman, E. (2008), “A Blueprint for Sovereign Wealth Fund Best Practices,” Peterson Institute for International Economics, Policy Brief No. PB08-3, Washington DC.

Walsh, Carl. (1995), “Optimal Contracts for Central Bankers,” American Economic Review 85: 150-167

Ziemba, Rachel (2008), “So How Large Are Sovereign Wealth Funds?” Roubini Global Economics Monitor, April 2.

Figure 1.

Figures and Tables 


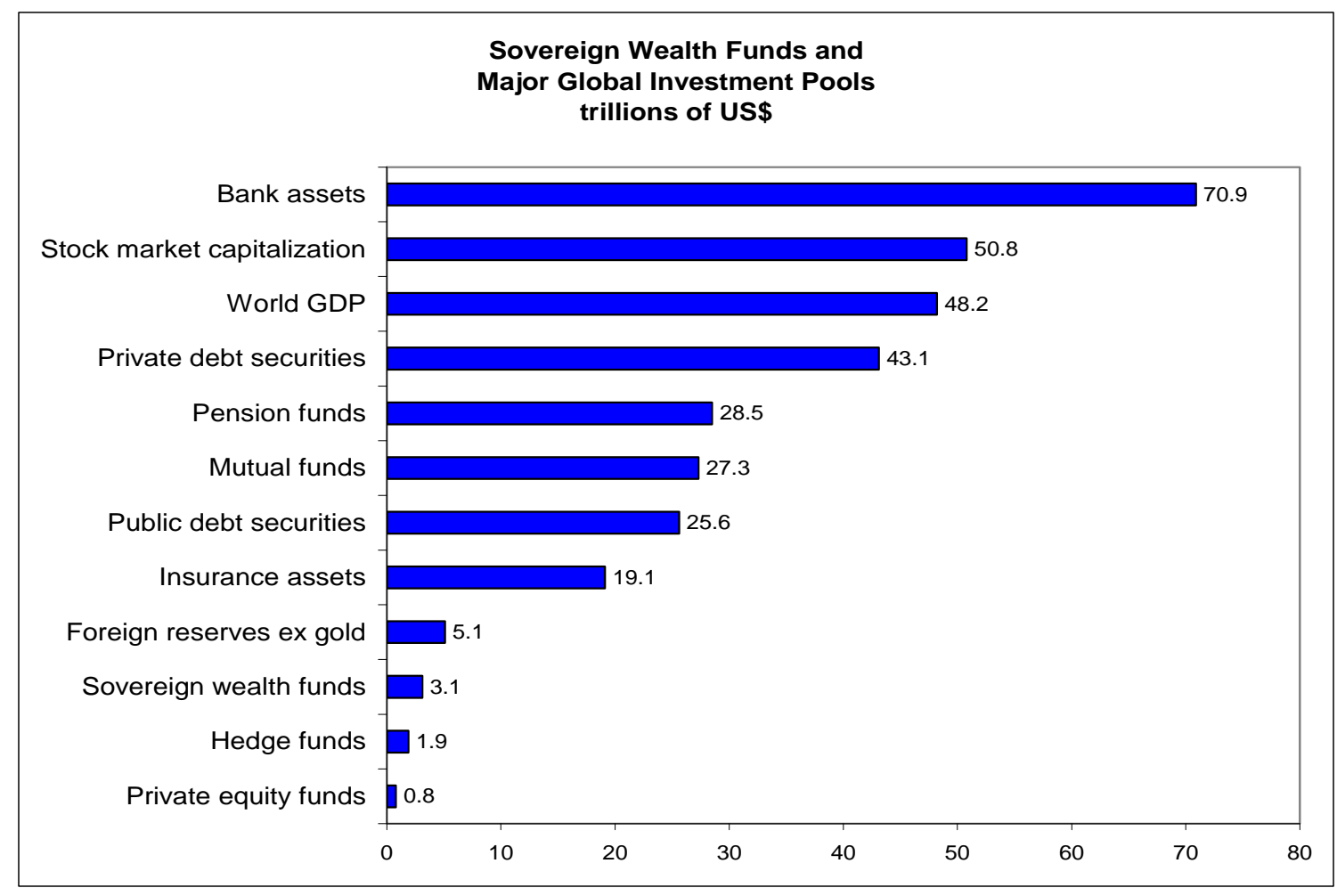

Source: IMF (2007) and Maslakovic (2008)

Figure 2.

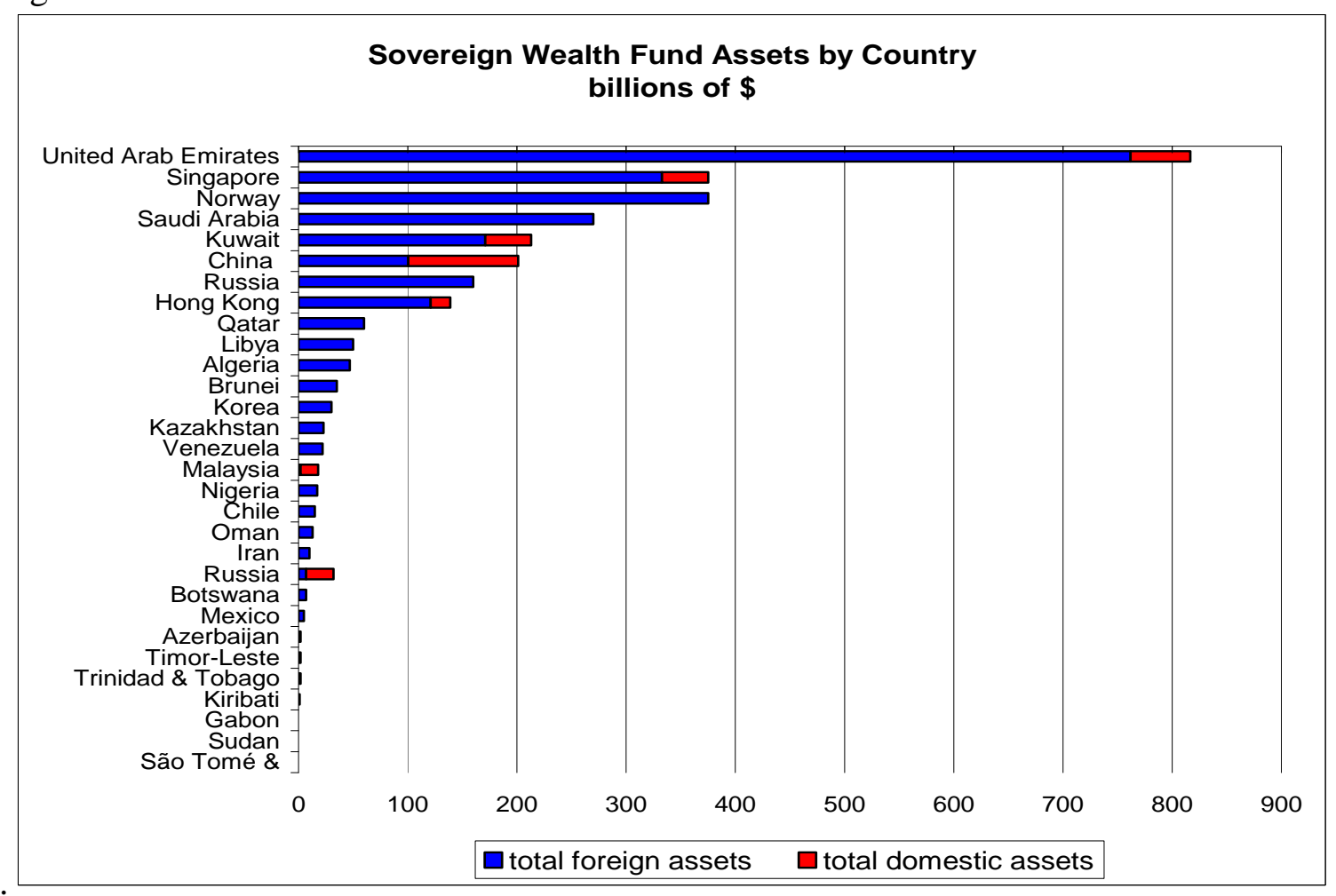


Figure 3.

Fuel Exports I Total Exports (percent)

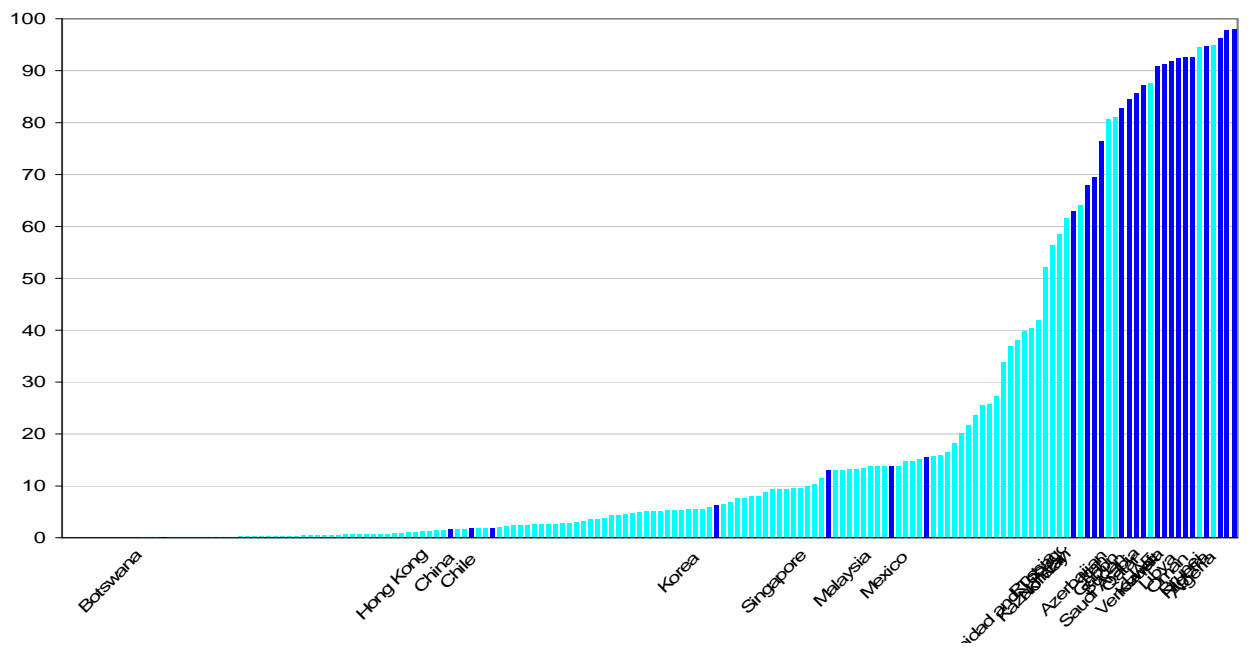

Figure 4.

Current Account/GDP (percent)

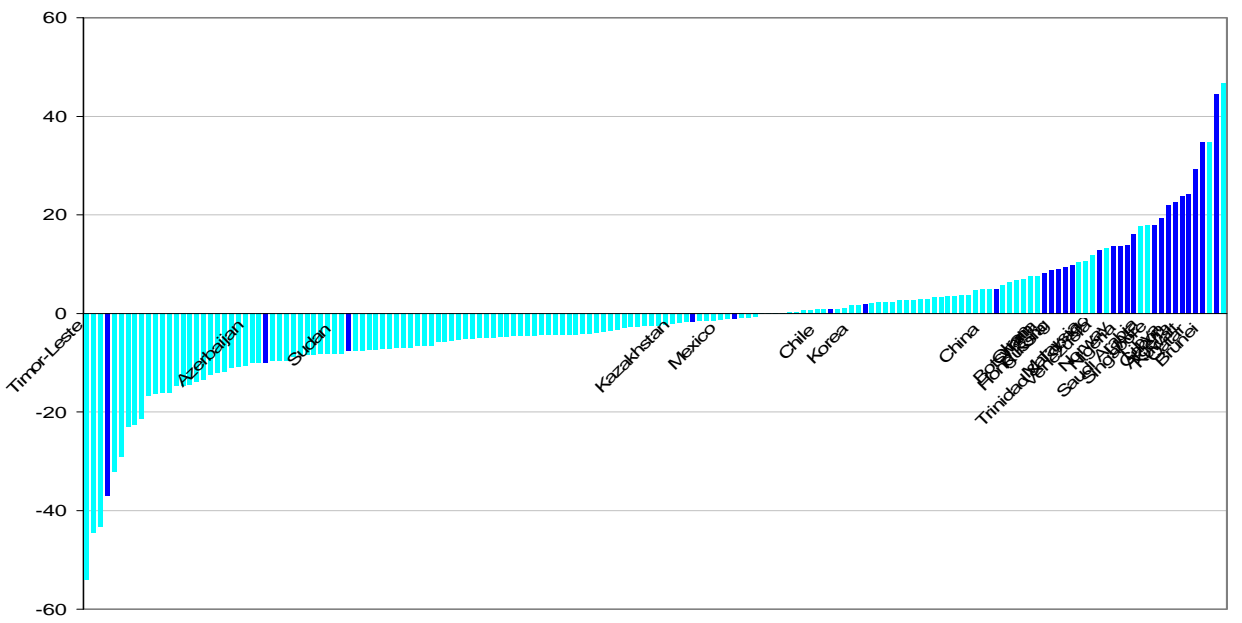


Figure 5.

GDP/Capita (2000 US\$)

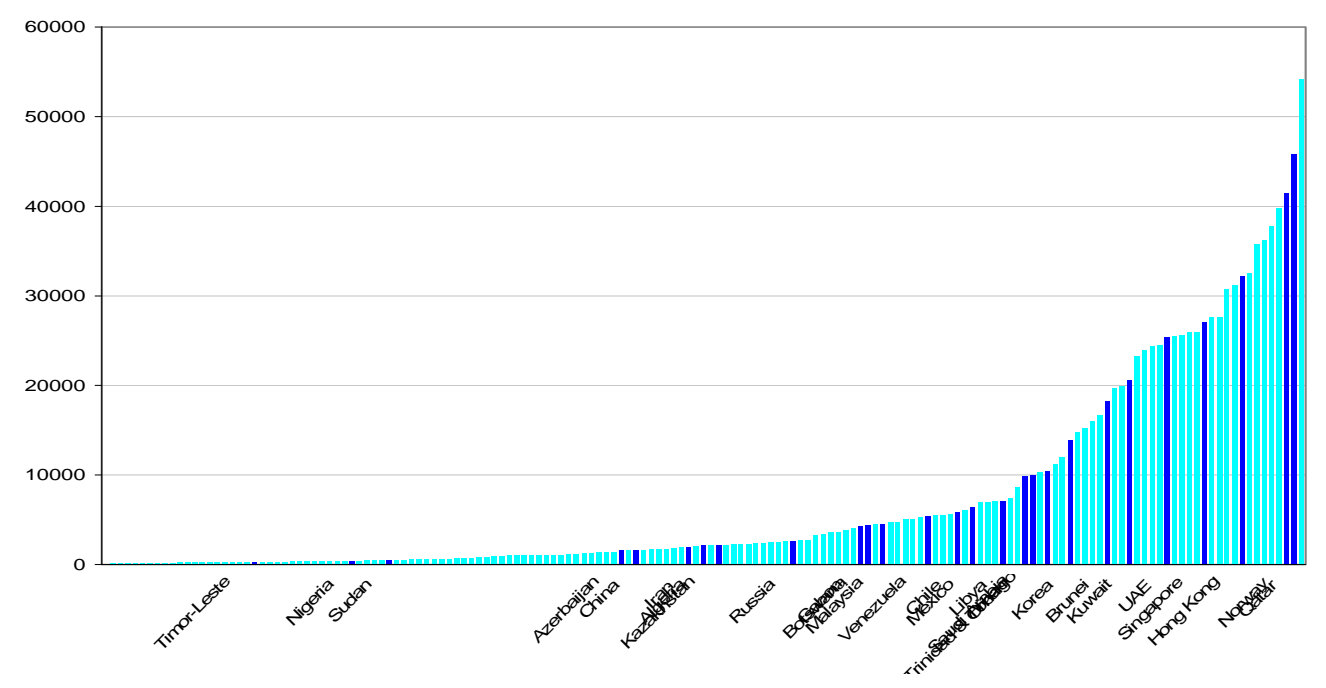

Figure 6.

Foreign Reserves / GDP (percent)

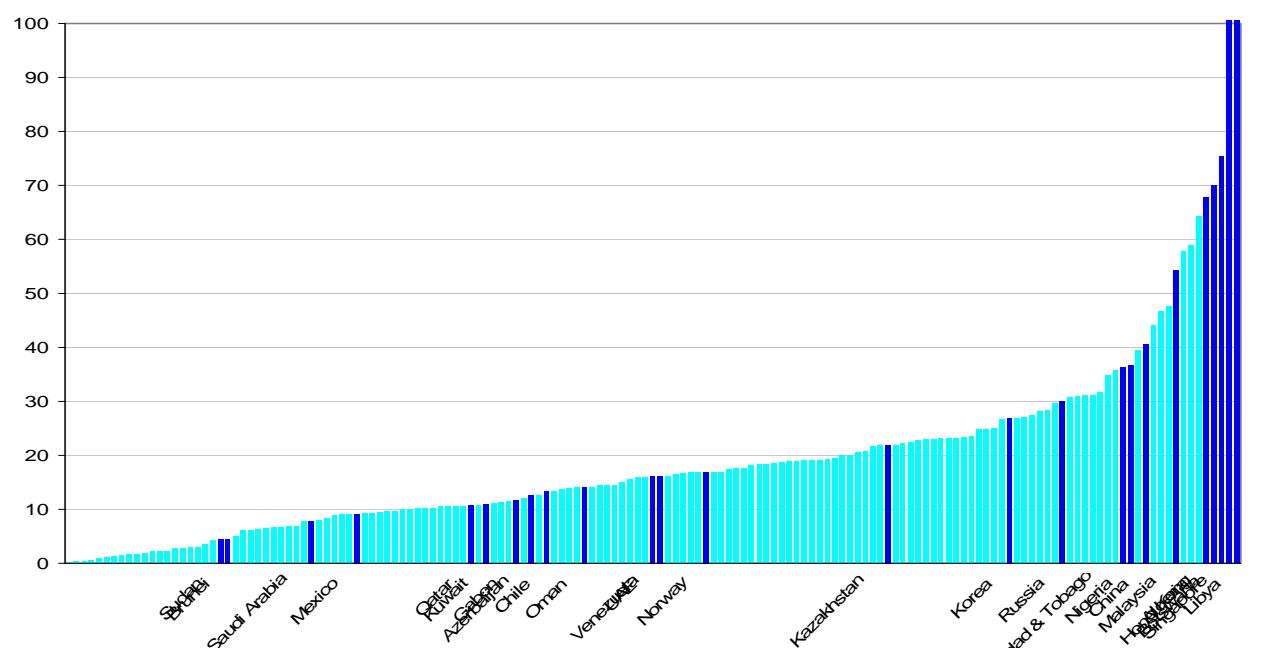


Figure 7.

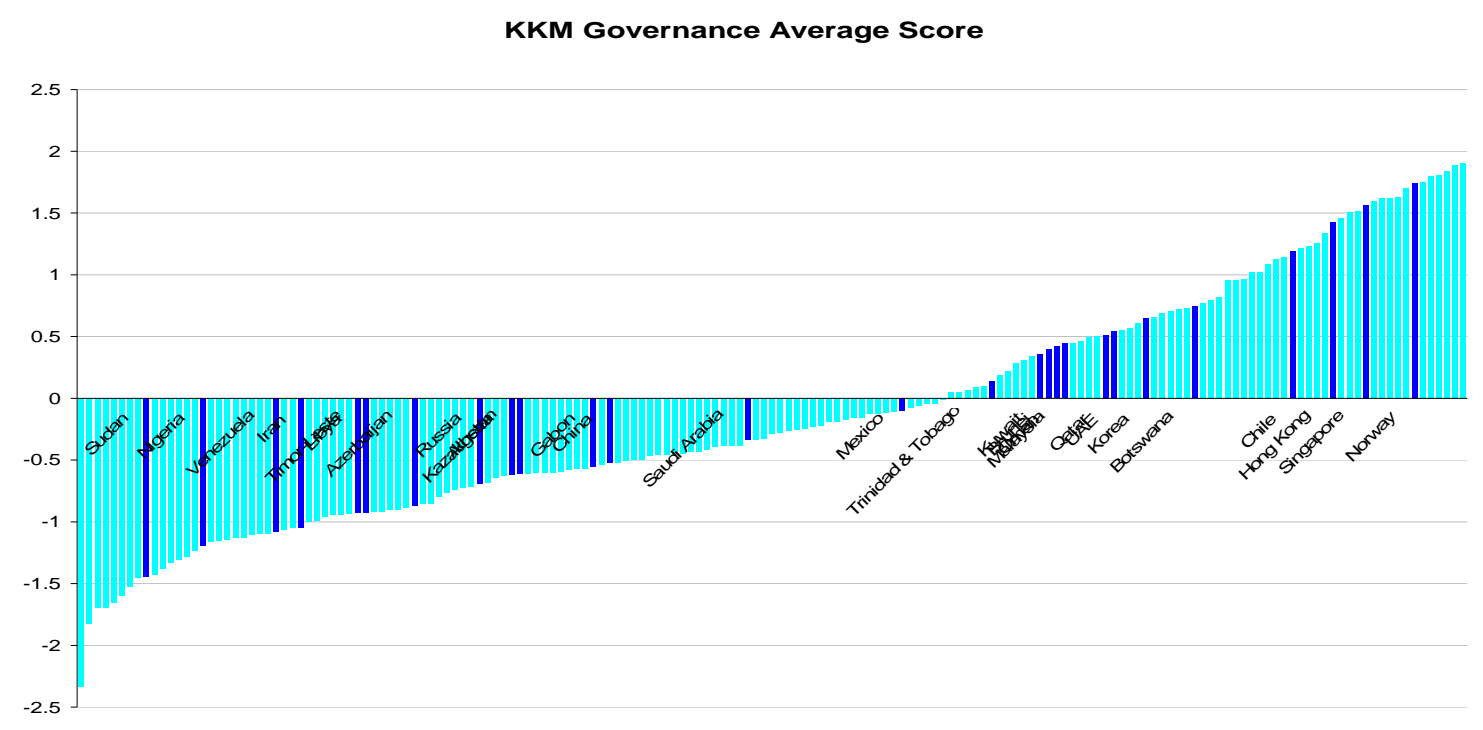

Figure 8.

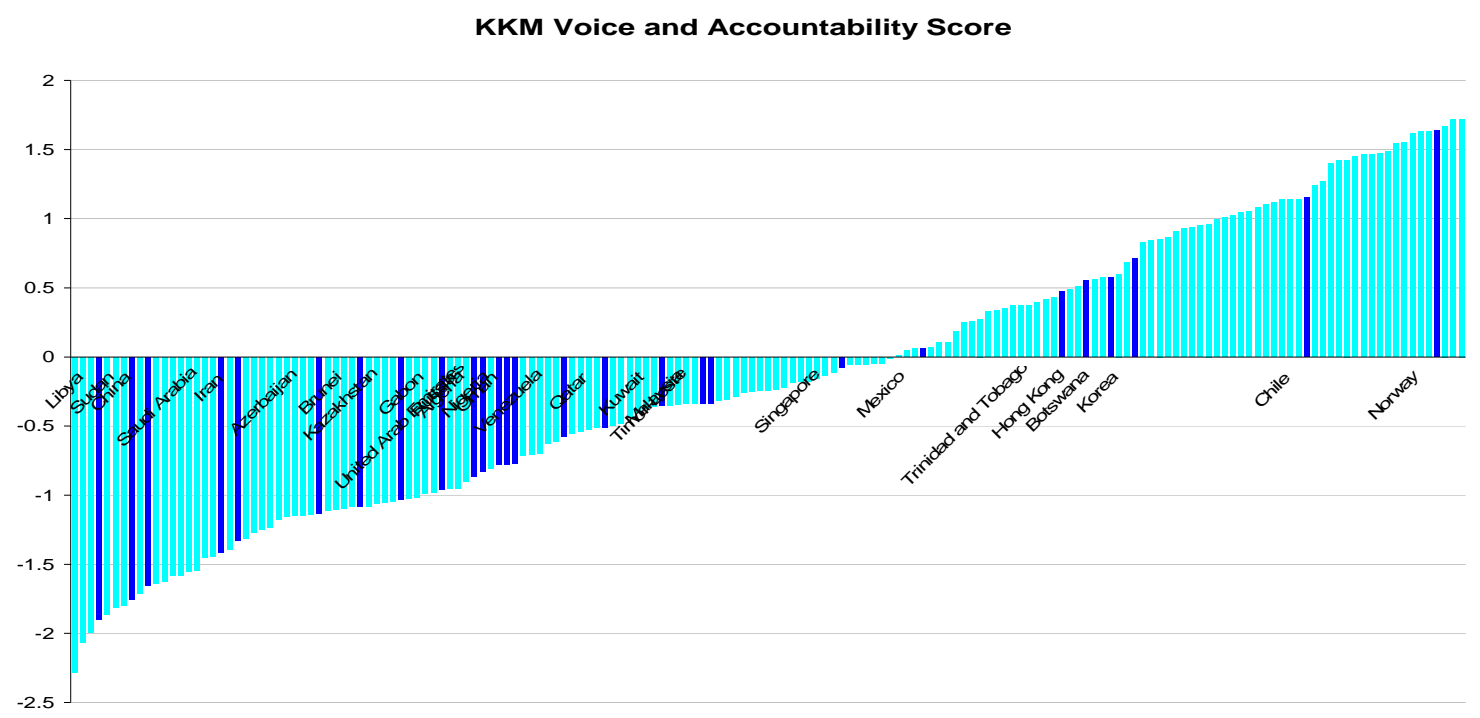


Figure 9.

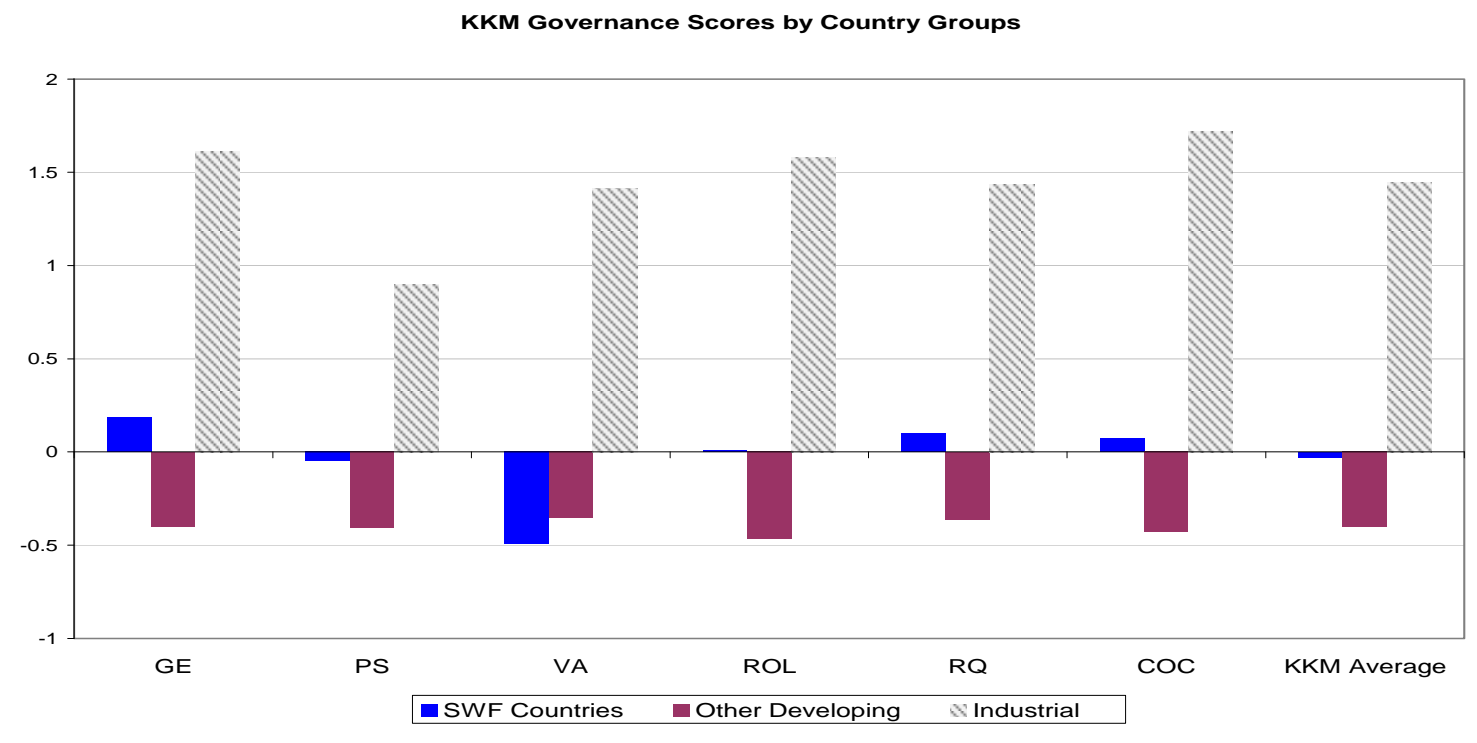

Note: KKM governance categories defined as GE=government effectiveness, $\mathrm{PS}=$ political stability and the absence of violence, $\mathrm{VA}=$ voice and accountability, $\mathrm{ROL}=$ rule of law, $\mathrm{RQ}=$ regulatory quality, and COC= control of corruption. Higher values associated with "better" governance. 
Figure 10.

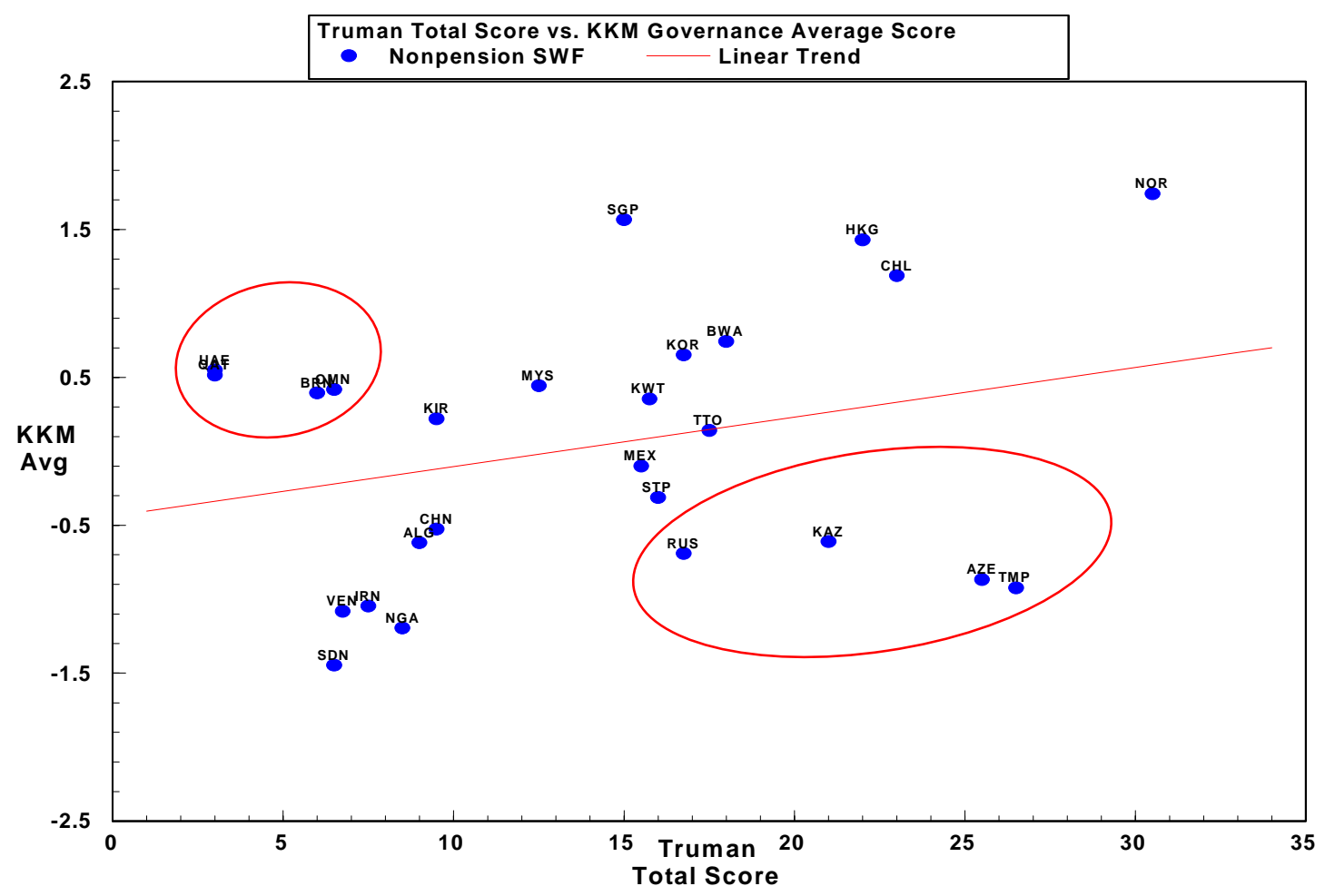

Figure 11.

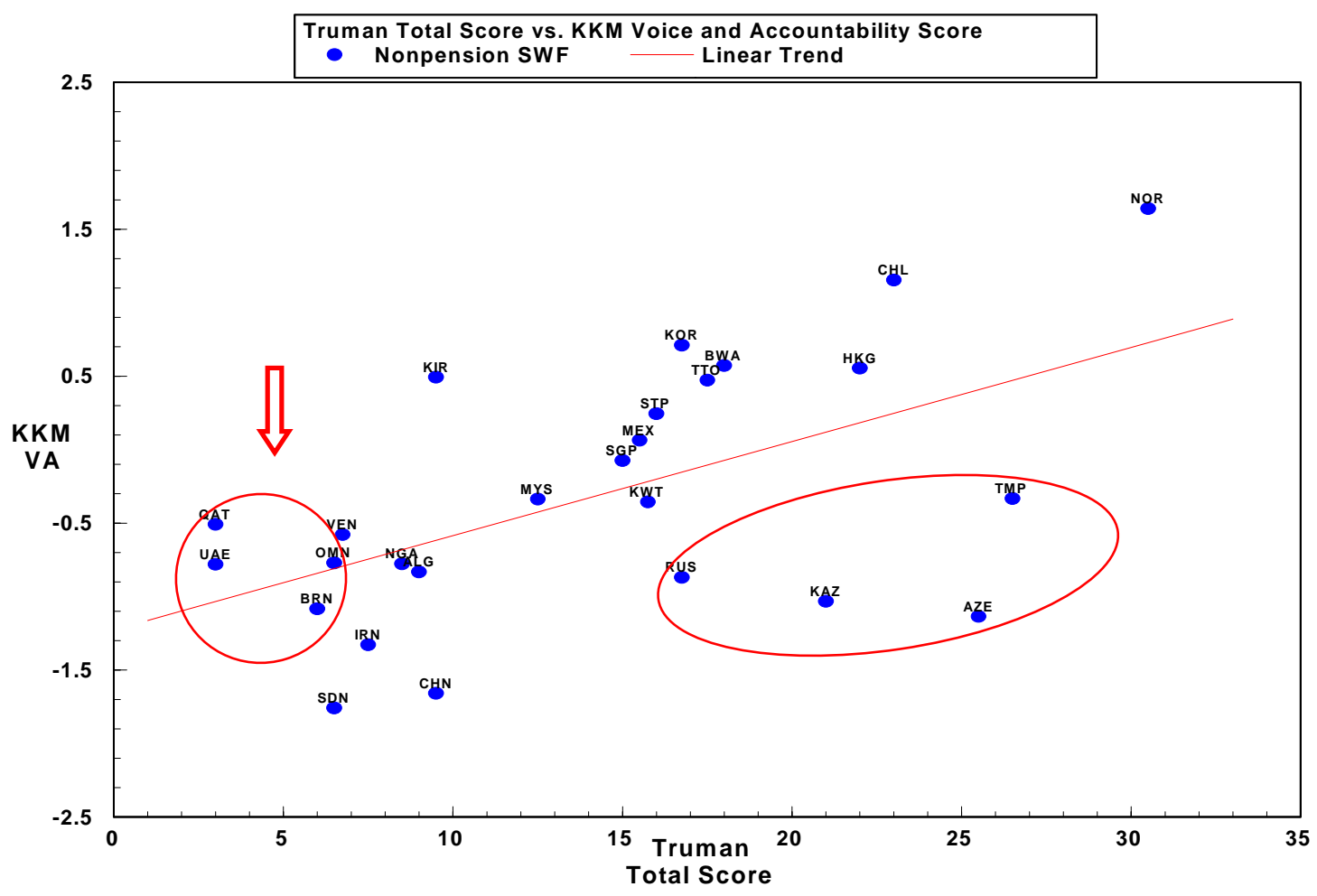


Figure 12.

Truman Scores for Different Sovereign Fund Groupings

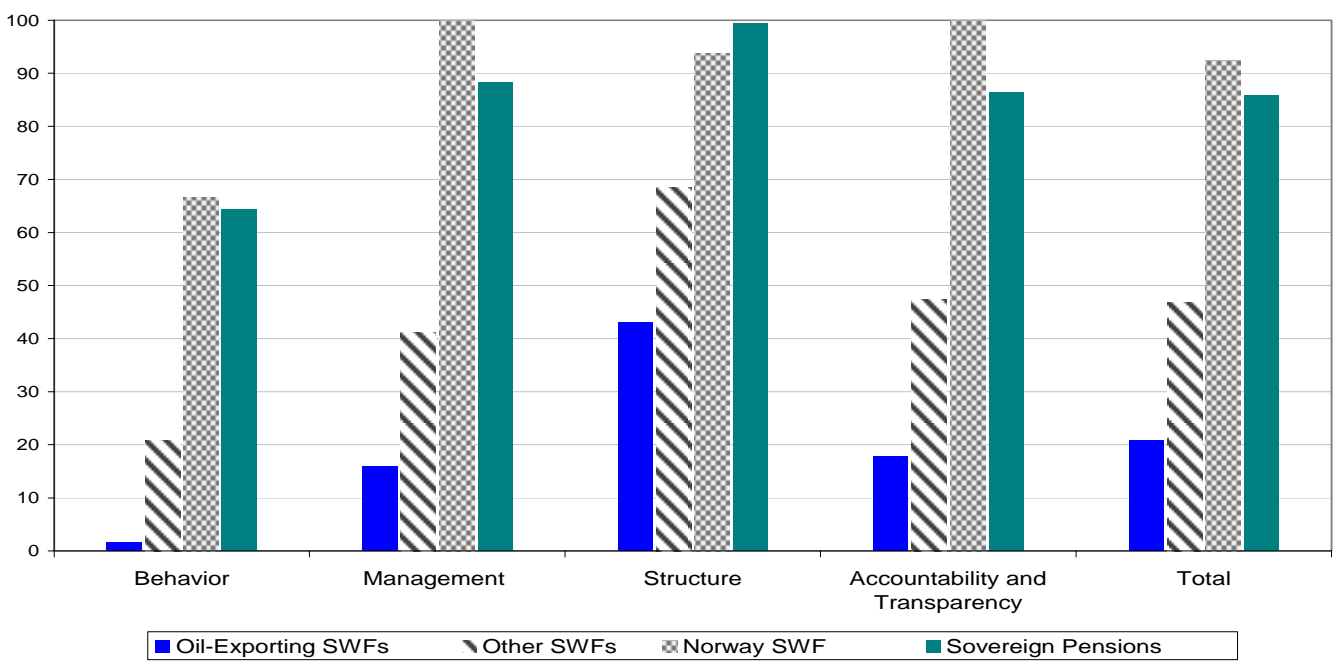

Note: scores normalized as a percent of maximum score possible per category

Figure 13.

KKM Governance Measures for Different Sovereign Fund Groupings

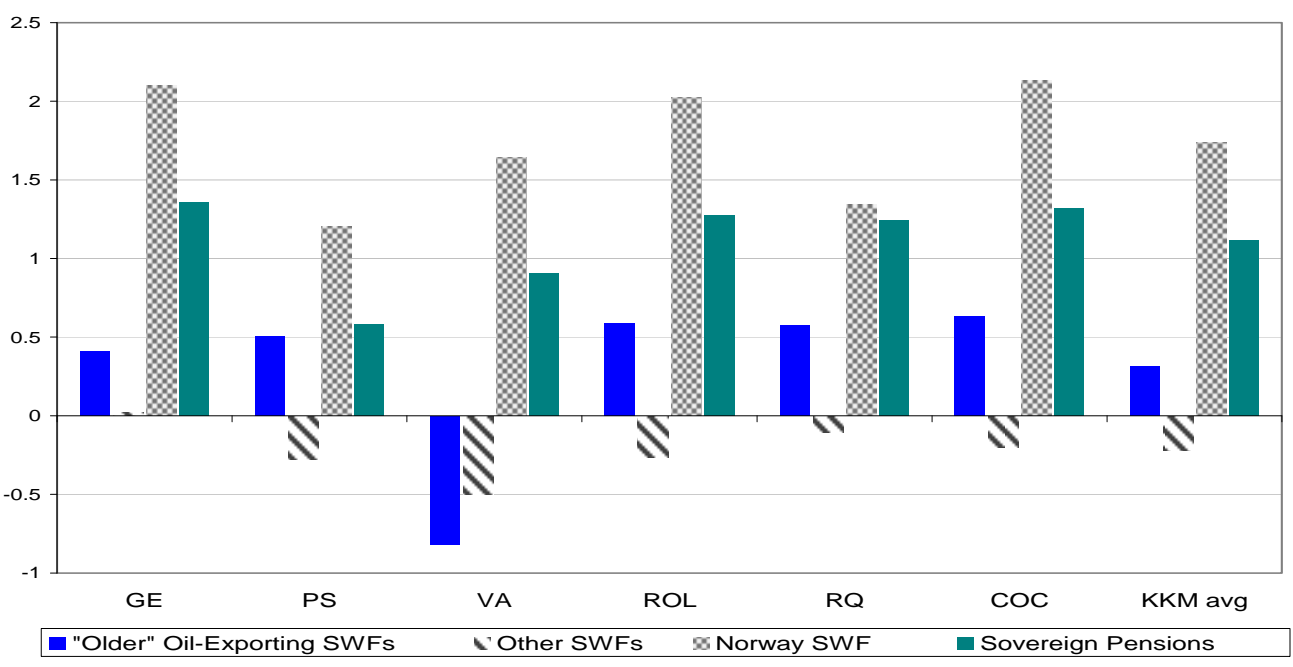

Note: KKM governance categories defined as GE=government effectiveness, $\mathrm{PS}=$ political stability and the absence of violence, $\mathrm{VA}=$ voice and accountability, ROL= rule of law, $\mathrm{RQ}=$ regulatory quality, and $\mathrm{COC}=$ control of corruption. 
Figure 14.

SWF Assets/GDP and Foreign Reserves/GDP (percent) Ordered by Date of SWF Establishment

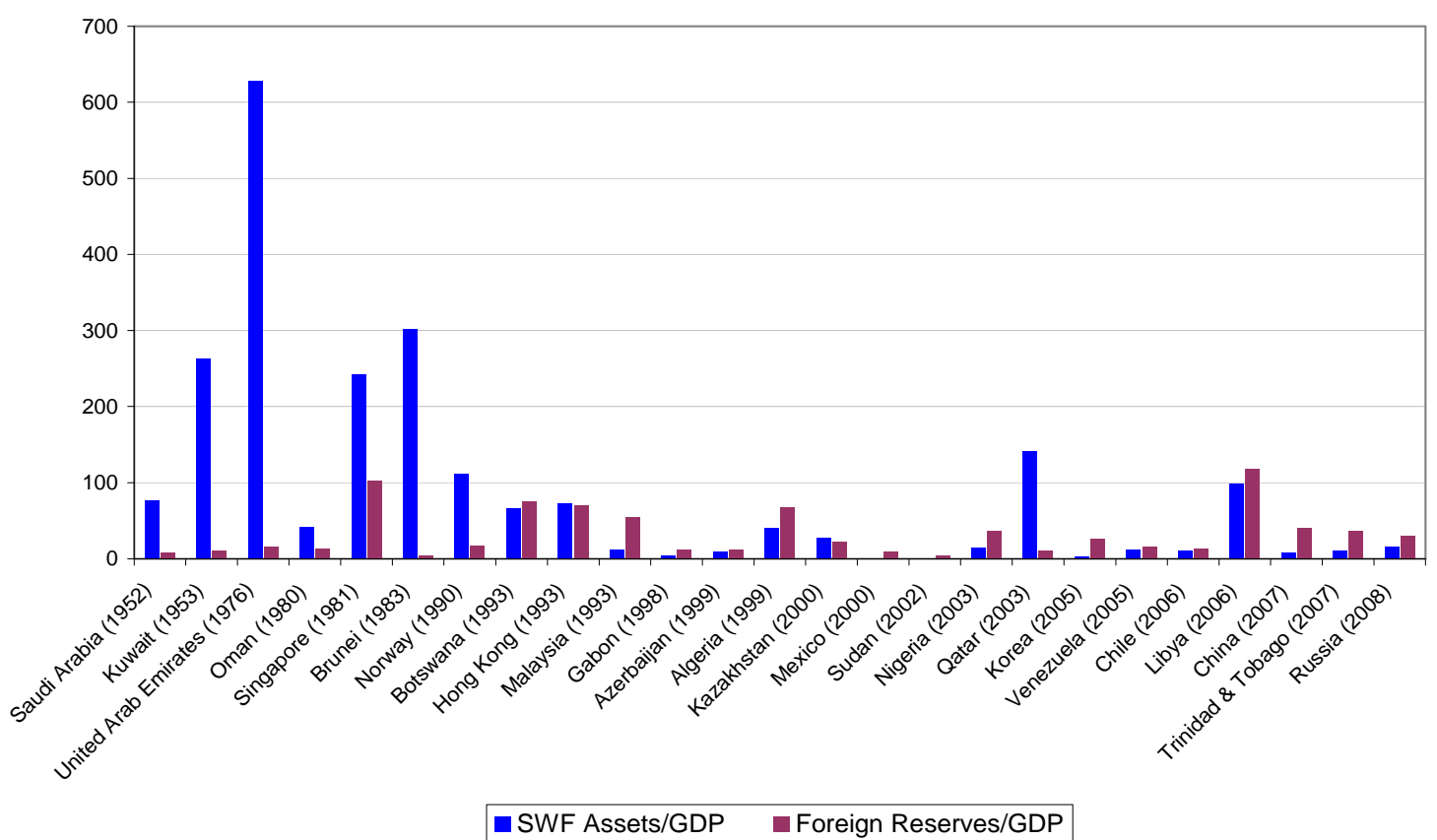

Figure 15.

SWF Assets I Foreign Reserves (percent) Ordered by Date of SWF Establishment

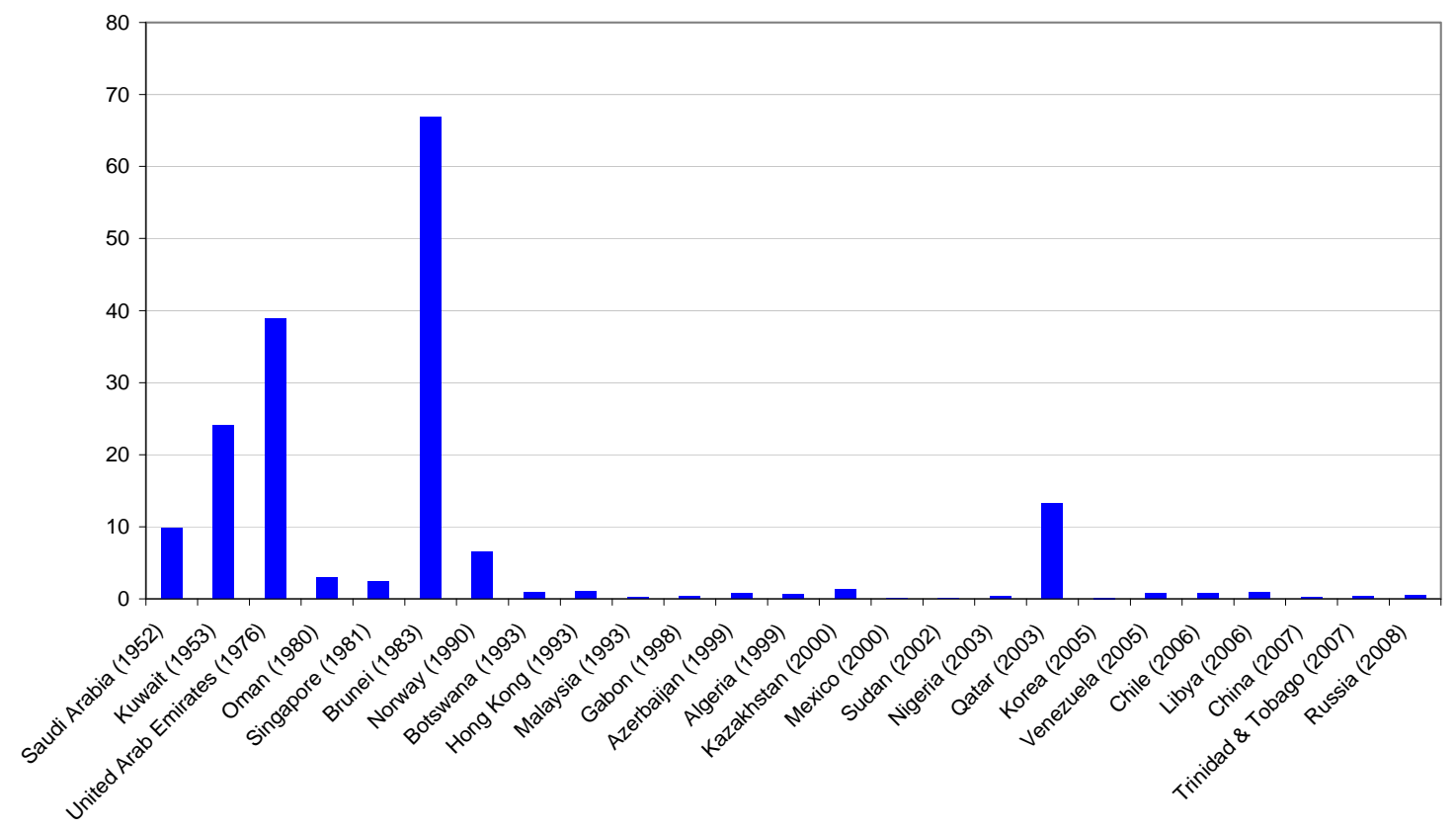


Table 1. Sovereign Wealth Fund Sample

\begin{tabular}{|c|c|c|c|}
\hline Country & Fund Name & $\begin{array}{c}\text { Date } \\
\text { Established }\end{array}$ & $\begin{array}{l}\text { Total assets } \\
(\$ \text { bil. })\end{array}$ \\
\hline United Arab Emirates & Abu Dhabi Investment Authority and others & 1976 & $817^{\mathrm{a}}$ \\
\hline Singapore & GIC, Temasek & 1981 & $375^{b}$ \\
\hline Norway & Government Pension Fund-Global & 1990 & 375 \\
\hline Saudi Arabia ${ }^{\mathrm{C}}$ & Saudi Arabian Monetary Agency & 1952 & 270 \\
\hline Kuwait & Kuwait Investment Authority & 1953 & 213 \\
\hline China & China Investment Corporation & 2007 & 201 \\
\hline Russia & Reserve Fund, National Welfare Fund & 2008 & 202 \\
\hline Hong Kong & Exchange Fund Investment Portfolio & 1993 & 139 \\
\hline Qatar & Qatar Investment Authority & 2005 & 60 \\
\hline Libya $^{c}$ & Libyan Investment Authority & 2006 & 50 \\
\hline Algeria & Revenue Regulation Fund & 2000 & 47 \\
\hline Brunei & Darussalam Brunei Investment Agency & 1983 & 35 \\
\hline Korea & Korea Investment Corporation & 2005 & 30 \\
\hline Kazakhstan & National Fund for the Republic of Kazakhstan & 2000 & 23 \\
\hline Venezuela & National Development Fund, Macro Stabilization Fund & 2005 & 22 \\
\hline Malaysia & Khazanah Nasionald & 1993 & 18 \\
\hline Nigeria & Excess Crude Account & 2003 & 17 \\
\hline Chile & Economic and Social Stabilization Fund & 2006 & 15 \\
\hline Oman & State General Reserve Fund & 1980 & 13 \\
\hline Iran & Oil Stabilization Fund & 2000 & 10 \\
\hline Botswana & Pula Fund & 1993 & 7 \\
\hline Mexico & Oil Income Stabilization Fund & 2000 & 5 \\
\hline Azerbaijan & State Oil Fund of the Republic of Azerbaijan & 1999 & 2 \\
\hline Timor-Leste & Petroleum Fund & 2005 & 2 \\
\hline Trinidad \& Tobago & Heritage and Stabilization Fund & 2007 & 2 \\
\hline Kiribati & Revenue Equalization Reserve Fund & 1956 & 1 \\
\hline Gabon $^{c}$ & Fund for Future Generations & 1998 & 0.4 \\
\hline Sudan & Oil Revenue Stabilization Account & 2002 & 0.1 \\
\hline São Tomé \& Príncipe & National Oil Account & 2004 & 0.02 \\
\hline TOTAL & & & 2909 \\
\hline $\begin{array}{l}\text { a Midpoint of estima } \\
\text { International Petrole } \\
\text { Dubai International } \\
{ }^{\mathrm{b}} \text { Midpoint of estima } \\
{ }^{\mathrm{c}} \text { Excluded from Tru }\end{array}$ & $\begin{array}{l}\text { ange for Abu Dhabi Investment Authority plus sum of a } \\
\text { Investment Company, Mubadala Development Compa } \\
\text { oital, Investment Corporation of Dubai, Istithmar World } \\
\text { for GIC plus assets of Temasek } \\
\text { n’s scoreboard. }\end{array}$ & $\begin{array}{l}\text { sets of Abu Dl } \\
\text {, Dubai DIF }\end{array}$ & $\begin{array}{l}\text { habi } \\
\text { 'C Investments, }\end{array}$ \\
\hline $\begin{array}{l}\text { Source Truman ( } 200 \\
\text { fund exists per count }\end{array}$ & $\begin{array}{l}\text { Data are from the end of } 2007 \text { or the } \\
\text { size computed as total of all funds, }\end{array}$ & le. $\mathrm{W}$ & nore than one \\
\hline
\end{tabular}


Table 2. Determinants of SWF Likelihood

\begin{tabular}{llcrlll}
\hline Explanatory Variable & \multicolumn{1}{c}{$(1)$} & $(2)$ & $(3)$ & \multicolumn{1}{c}{$(4)$} & \multicolumn{1}{c}{$(5)$} & \multicolumn{1}{c}{$(6)$} \\
\hline Current account/GDP & 0.1 .014 & & & 0.767 & 0.758 & 0.485 \\
& $(0.27)^{\star \star \star}$ & & & $(0.27)^{\star \star \star}$ & $(0.30)^{\star \star}$ & $(0.22)^{\star \star}$ \\
Fuel/total exports & & 0.464 & & 0.309 & 0.344 & 0.351 \\
& & $(0.09)^{\star \star \star}$ & & $(0.09)^{\star \star \star}$ & $(0.10)^{\star \star \star}$ & $(0.10)^{\star \star \star}$ \\
Ore\&metals/total exports & & & -0.312 & 0.079 & 0.095 & 0.137 \\
& & & $(0.26)$ & $(0.17)$ & $(0.18)$ & $(0.16)$ \\
GDP per capita & & & & & 0.167 & \\
& & & & & $(0.18)$ & \\
Foreign reserves/GDP & & & & & & $0.378^{\star \star \star}$ \\
Observations & & & & & & $(0.14)$ \\
Log likelihood & 166 & 168 & 169 & 162 & 159 & 154 \\
Pseudo R-sq & -59.232 & -47.503 & -71.297 & -40.327 & -38.446 & -32.63 \\
& 0.196 & 0.344 & 0.017 & 0.435 & 0.457 & 0.522
\end{tabular}

Note: The table reports the change in the probability of existence of a SWF in 2007 or 2008 in response to a 1 unit change in the variable evaluated at the mean of all variables (x100) to convert into percentages with associated standard errors (for hypothesis of no effect) in parentheses below. Significance at $1 \%$, $5 \%, 10 \%$ indicated by $* * *$, **, and *, respectively, using robust errors. Constants included, but not reported. Sample confined to countries with populations greater than 250,000 people in 2006. 
Table 3. Determinants of SWF Likelihood: KKM Governance Indicators

\begin{tabular}{|c|c|c|c|c|c|c|c|}
\hline Explanatory Variable & (1) & (2) & (3) & (4) & (5) & (6) & (7) \\
\hline KKM Governance Average & $\begin{array}{l}1.545 \\
(2.85)\end{array}$ & & & & & & \\
\hline Government Effectiveness & & $\begin{array}{l}3.671 \\
(2.47)\end{array}$ & & & & & \\
\hline Political Stability & & & $\begin{array}{l}2.342 \\
(2.94)\end{array}$ & & & & \\
\hline Voice and Accountability & & & & $\begin{array}{l}-5.577 \\
(2.73)^{\star \star}\end{array}$ & & & \\
\hline Rule of Law & & & & & $\begin{array}{l}2.252 \\
(2.63)\end{array}$ & & \\
\hline Regulatory Quality & & & & & & $\begin{array}{l}2.609 \\
(2.75)\end{array}$ & \\
\hline Control of Corruption & & & & & & & $\begin{array}{l}0.02328 \\
(2.62)\end{array}$ \\
\hline Observations & 171 & 171 & 171 & 171 & 171 & 171 & 171 \\
\hline Log likelihood & -74.449 & -73.658 & -74.247 & -72.608 & -74.245 & -74.139 & -74.212 \\
\hline Pseudo R-sq & 0.002 & 0.012 & 0.005 & 0.027 & 0.005 & 0.006 & 0.005 \\
\hline
\end{tabular}

Table 4. Determinants of SWF Likelihood: KKM Governance Indicators Developing Countries Only

\begin{tabular}{|c|c|c|c|c|c|c|c|}
\hline Explanatory Variable & (1) & (2) & (3) & (4) & (5) & (6) & (7) \\
\hline KKM Governance Average & $\begin{array}{l}7.897 \\
(4.18)^{\star}\end{array}$ & & & & & & \\
\hline Government Effectiveness & & $\begin{array}{l}10.858 \\
(3.50)^{\star \star \star}\end{array}$ & & & & & \\
\hline Political Stability & & & $\begin{array}{l}5.348 \\
(3.59)\end{array}$ & & & & \\
\hline Voice and Accountability & & & & $\begin{array}{l}-4.584 \\
(3.68)\end{array}$ & & & \\
\hline Rule of Law & & & & & $\begin{array}{l}9.051 \\
(3.93)^{\star \star}\end{array}$ & & \\
\hline Regulatory Quality & & & & & & $\begin{array}{l}7.892 \\
(3.73)^{\star \star}\end{array}$ & \\
\hline Control of Corruption & & & & & & & $\begin{array}{l}10.333 \\
(4.02)^{\star \star}\end{array}$ \\
\hline Observations & 148 & 148 & 148 & 148 & 148 & 148 & 148 \\
\hline Log likelihood & -66.907 & -64.416 & -67.511 & -68.037 & -65.968 & -66.258 & -65.375 \\
\hline Pseudo R-sq & 0.0273 & 0.0635 & 0.0185 & 0.011 & 0.0410 & 0.0368 & 0.0500 \\
\hline
\end{tabular}


Table 5. Correlation of National and SWF Governance Indicators

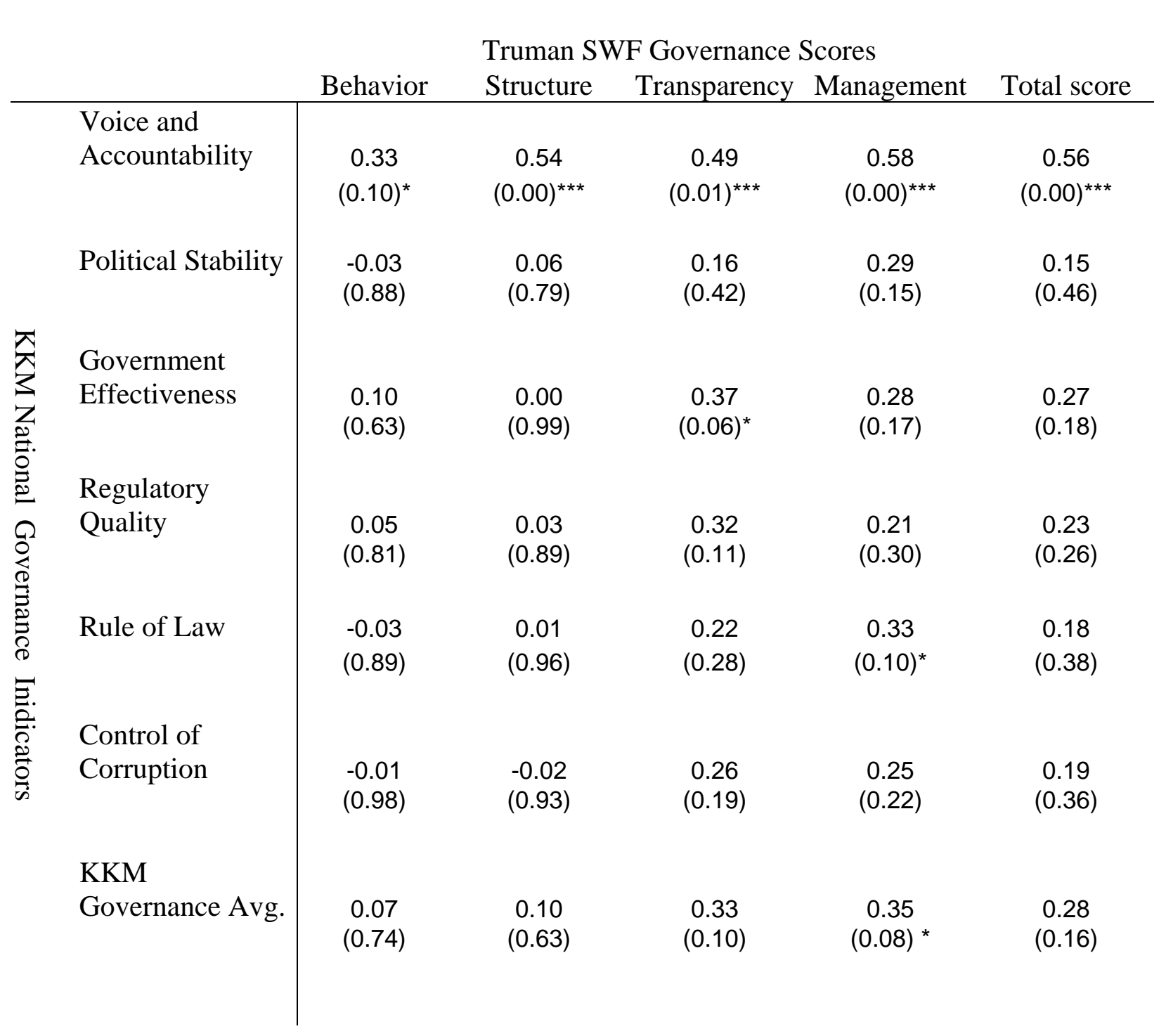

Note: Table reports correlation of Truman (2008) scores for 26 sovereign (nonpension) wealth funds listed in Table 1 with Kaufmann, Kraay, and Mastruzzi (2007) national governance measures for corresponding countries of origin. P-values in parentheses below. Significance at $1 \%, 5 \%, 10 \%$ indicated by $* * *, * *$, and $*$, respectively. 
Table 6. Determinants of SWF Assets/GDP with Truman SWF Scores

\begin{tabular}{|c|c|c|c|c|c|c|c|}
\hline Explanatory Variable & (1) & (2) & (3) & (4) & (5) & (6) & (7) \\
\hline Fuel exports/GDP & $\begin{array}{l}3.106 \\
(1.485)^{\star \star}\end{array}$ & $\begin{array}{l}2.186 \\
(1.282)\end{array}$ & $\begin{array}{l}2.013 \\
(1.188)^{\star}\end{array}$ & $\begin{array}{l}2.451 \\
(1.587)\end{array}$ & $\begin{array}{l}1.761 \\
(1.075)^{*}\end{array}$ & $\begin{array}{l}1.962 \\
(1.080)^{*}\end{array}$ & $\begin{array}{l}2.249 \\
(1.240)^{*}\end{array}$ \\
\hline SWF Duration & & $\begin{array}{l}3.932 \\
(2.057)^{\star}\end{array}$ & $\begin{array}{l}6.367 \\
(2.366)^{\star \star}\end{array}$ & $\begin{array}{l}6.181 \\
(2.329)^{\star *}\end{array}$ & $\begin{array}{l}6.154 \\
(1.916)^{\star \star \star}\end{array}$ & $\begin{array}{l}6.355 \\
(2.131)^{\star \star \star}\end{array}$ & $\begin{array}{l}6.250 \\
(2.471)^{\star *}\end{array}$ \\
\hline Total Fund Score & & & $\begin{array}{l}-1.920 \\
(2.133)\end{array}$ & & & & \\
\hline Fund Behavior & & & & $\begin{array}{l}4.620 \\
(14.515)\end{array}$ & & & \\
\hline Fund Structure & & & & & $\begin{array}{l}-19.853 \\
(10.523)^{*}\end{array}$ & & \\
\hline Fund Transparency & & & & & & $\begin{array}{l}-12.860 \\
(15.845)\end{array}$ & \\
\hline Fund Management & & & & & & & $\begin{array}{l}-1.090 \\
(4.076)\end{array}$ \\
\hline Observations & 26 & 26 & 23 & 23 & 23 & 23 & 23 \\
\hline R2 & 0.245 & 0.370 & 0.527 & 0.520 & 0.570 & 0.532 & 0.520 \\
\hline
\end{tabular}

Table 7. Determinants of SWF Assets/GDP with KKM Governance Indicators

\begin{tabular}{|c|c|c|c|c|c|c|c|}
\hline Explanatory Variable & (1) & (2) & (3) & (4) & (5) & (6) & (7) \\
\hline Fuel exports/GDP & $\begin{array}{l}3.032 \\
(1.406)^{\star \star}\end{array}$ & $\begin{array}{l}3.310 \\
(1.413)^{\star \star}\end{array}$ & $\begin{array}{l}2.379 \\
(1.260)^{*}\end{array}$ & $\begin{array}{l}2.690 \\
(1.542)^{\star}\end{array}$ & $\begin{array}{l}2.944 \\
(1.372)^{\star \star}\end{array}$ & $\begin{array}{l}3.032 \\
(1.473)^{\star}\end{array}$ & $\begin{array}{l}3.076 \\
(1.332)^{\star \star}\end{array}$ \\
\hline SWF Duration & $\begin{array}{l}2.191 \\
(1.720)\end{array}$ & $\begin{array}{l}2.090 \\
(1.606)\end{array}$ & $\begin{array}{l}2.875 \\
(1.638)^{*}\end{array}$ & $\begin{array}{l}3.703 \\
(2.021)^{\star}\end{array}$ & $\begin{array}{l}1.811 \\
(1.813)\end{array}$ & $\begin{array}{l}2.117 \\
(1.927)\end{array}$ & $\begin{array}{l}1.389 \\
(1.720)\end{array}$ \\
\hline Governance Average & $\begin{array}{l}66.937 \\
(25.777)^{\star \star}\end{array}$ & & & & & & \\
\hline Govt. Effectiveness & & $\begin{array}{l}71.428 \\
(25.107)^{\star \star \star \star}\end{array}$ & & & & & \\
\hline Political Stability & & & $\begin{array}{l}52.097 \\
\left(18.447^{\star \star \star}\right.\end{array}$ & & & & \\
\hline Voice and Accountability & & & & $\begin{array}{l}30.077 \\
(22.159)\end{array}$ & & & \\
\hline Rule of Law & & & & & $\begin{array}{l}60.192 \\
(22.478)^{\star \star}\end{array}$ & & \\
\hline Regulatory Quality & & & & & & $\begin{array}{l}60.223 \\
(25.449)^{\star *}\end{array}$ & \\
\hline Control of Corruption & & & & & & & $\begin{array}{l}68.669 \\
(24.301) \text { ** }\end{array}$ \\
\hline Observations & 26 & 26 & 26 & 26 & 26 & 26 & 26 \\
\hline R2 & 0.502 & 0.545 & 0.479 & 0.375 & 0.484 & 0.490 & 0.546 \\
\hline
\end{tabular}


Table 8. Determinants of Foreign Reserves/GDP

\begin{tabular}{llll}
\hline Explanatory Variable & \multicolumn{1}{c}{$(1)$} & $(2)$ \\
\hline Reserve volatility & -0.151 & -0.183 \\
& $(0.702)$ & $(0.702)$ \\
Imports/GDP & 0.098 & 0.100 \\
& $(0.043)^{* *}$ & $(0.044)^{* *}$ \\
M2/GDP & 0.124 & 0.126 \\
& $(0.029)^{* * *}$ & $(0.029)^{* * *}$ \\
Currency Crisis & -2.036 & -2.056 \\
& $(0.657)^{* * *}$ & $(0.658)^{* * *}$ \\
SWF present & 6.595 & 7.057 \\
& $(3.189)^{* *}$ & $(3.197)^{* *}$ \\
SWF “older” oil exporter & & -6.618 \\
& & $(3.324)^{* *}$ \\
Observations & 2151 & 2151 \\
No. of Countries & 116 & 116 \\
No. of Countries with SWFs & 22 & 22 \\
R2 (overall) & 0.380 & 0.414
\end{tabular}

Table reports results of panel regression over 1985-2006, with random effects and robust errors clustered by country. Dummy variable for SWF "older" oil exporters defined as oil-exporting country with SWF established before 1990. 


\section{Appendix: Modeling Asset Diversification by a Central Bank and Sovereign Wealth Fund}

This Appendix compares the optimal patterns of portfolio diversification managed by a central bank (CB) and a sovereign wealth fund (SWF), possibly acting as an agent for the Treasury.

We first present a simple model with which we compare the optimal degree of diversification depending on the authorities' utility function. We assume that the objective of the $\mathrm{CB}$ is to maintain financial stability by solely focusing on the objective of reducing the probability of sudden stops. In contrast, we presume that the Treasury, acting through a SWF, maximizes the expected utility of a representative domestic agent. In this framework we show that the CB's focus on financial stability implies that it will place a higher weight on the downside risk of sudden stops than will the SWF. Consequently, the CB tends to bias its portfolio strategy towards holding more of the safe asset, whereas the SWF opts for greater diversification towards risky foreign assets. We also show how the diversification gap between the strategies of the CB and SWF is affected by various parameters of the economy, such as the volatility of equity returns.

We follow with a more elaborate model of joint decision making in which we treat the Treasury as the dominant player and assume that it sets the total level of foreign assets managed by the central bank, but delegates to the central bank the responsibility for maintaining financial stability through the composition of its portfolio. Conditional on the actions of the central bank, the Treasury decides what level of public foreign assets to entrust to the central bank for management as well as the composition of the residual share of the country's public foreign assets managed through the SWF. In these circumstances, we find that the assignment of the objective to financial stability to the $\mathrm{CB}$ tends to increase the gap between the optimal diversification patterns of the CB and the SWF.

In the concluding section we discuss how the degree of a country's internal and external transparency affects the country’s foreign asset returns and management.

\section{A1. The Base Model}

We consider the case where the authorities - either a central bank (CB) or a sovereign wealth fund (SWF) -- determine the diversification of a given initial level of public foreign asset 
holdings, $A$, between risk-free international reserves, $R$ and risky foreign equities $F$, such that $A$ $=R+F$. International reserves yield a gross risk-free interest rate $r_{0}$, whereas equity yields a stochastic return $r_{0}+e+\delta$, where $e$ is the expected equity premium and $\delta$ is a zero mean equity-return shock. The realized value of public foreign assets in the following period, $A_{1}$, is given by

$$
A_{1}=r_{0} A+(e+\delta) F ; \quad 0 \leq F \leq A .
$$

The probability of a sudden stop, $\phi$, depends negatively on the public sector's foreign assets, $A_{1}$, and positively on the exogenously given level of aggregate foreign liabilities, $B$, such that $\phi=\phi\left[B / A_{1}\right] ; \quad \phi^{\prime}>0 .{ }^{1}$ In these circumstances, greater diversification towards foreign equities entails growing balance sheet vulnerability, where adverse equity return shocks raise the probability of sudden stops.

The timing of the model is such that after determination of the degree of diversification of foreign assets between equities and international reserves, the equity return shock $(\delta)$ is realized at the beginning of the second period. This realization leads with probability $\phi$ to a sudden stop crisis. In the absence of a crisis, the external debt $B$ is repaid, and output $Y_{1}$ is realized, ${ }^{2}$ In the event of a sudden stop crisis, premature costly liquidation occurs, shrinking end-of-period output and foreign assets to $\left(Y_{1}+A_{1}\right)(1-\tau), 1 \geq \tau>0 .^{3}$

\footnotetext{
${ }^{1}$ In the background of the model agents finance long-term investment via banks, which intermediate short-term deposits into longer term investment a la Diamond and Dybvig (1983). The economy is assumed only partially integrated with the global financial system, hence some of the liquidity intermediated by the banking system is the outcome of inflows of short-term foreign deposits ("hot money"). Financial integration implies exposure to sudden stops and capital flight shocks, which may drain the liquidity of the domestic banking system. A sudden stop entails costly pre-mature liquidation of long term investments, reducing thereby the output associated with these projects. The sudden stop probability can be derived endogenously by allowing for liquidity shocks $z$ to foreign borrowing (see Aizenman and Lee, 2008). If $z<A_{1}$, the liquidity shock is financed by $A_{1}$, without disrupting long-term investment. If $z>A_{1}$, it leads to a sudden stop crisis associated with premature and costly liquidation of $z-A_{1}$ units of capital.

${ }^{2}$ The model can be generalized by endogenizing the determination of foreign borrowing $B$. For example, in a twoperiod economy, where second-period output is subject to productivity shocks, the possibility that the country may default in the second period with a bad enough productivity shock implies that foreign borrowing is constrained by the condition that the cost of funds equals the expected return to lenders (see Aizenman and Marion, 2004). $Y_{1}$ might be expressed as a function of borrowing $B$ in this more general framework.

${ }^{3}$ This is a reduced form of the resources left following the premature liquidation of investments needed to finance deposits and capital flight. To simplify, we assume that that $A_{1}$ and $Y_{1}$ shrink at the same rate. The logic of our analysis continues to hold with different shrinkage rates of $A_{1}$ and $Y_{1}$, where the resources left would be $A_{1}\left(1-\tau_{A}\right)+Y_{1}\left(1-\tau_{Y}\right), 1 \geq \tau_{A}>0,1 \geq \tau_{Y}>0$.
} 
Agents are risk averse, with utility $U$. The SWF determines the portfolio allocation in order to maximize the expected utility of a representative domestic agent, $V_{s w}$ :

$$
V_{s w}=E\left[\left\{1-\phi\left[B / A_{1}\right]\right\} U\left[A_{1}+Y_{1}-B\right]+\left\{\phi\left[B / A_{1}\right]\right\} U\left[\left(A_{1}+Y_{1}\right)(1-\tau)\right]\right],
$$

where $E$ is the expectation operator. Assuming an interior solution with diversification, the FOC determining $F$ is:

$$
\begin{gathered}
d V_{s w} / d F=E\left[(1-\phi) U^{\prime}\left[A_{1}+Y_{1}-B\right](e+\delta)+\phi U^{\prime}\left[\left(A_{1}+Y_{1}\right)(1-\tau)\right](1-\tau)(e+\delta)\right] \\
+E\left[\phi^{\prime} \frac{B}{\left(A_{1}\right)^{2}}(e+\delta)\left\{U\left[A_{1}+Y_{1}-B\right]-U\left[\left(A_{1}+Y_{1}\right)(1-\tau)\right]\right\}\right]=0 .
\end{gathered}
$$

Rearranging terms,

$$
E[d U / d F]=E\left[-\phi^{\prime} \frac{B}{\left(A_{1}\right)^{2}}(e+\delta)\left\{U\left[A_{1}+Y_{1}-B\right]-U\left[\left(A_{1}+Y_{1}\right)(1-\tau)\right]\right\},\right.
$$

where

$$
E[d U / d F] \equiv E\left[(1-\phi) U^{\prime}\left[A_{1}+Y_{1}-B\right](e+\delta)+\phi U^{\prime}\left[\left(A_{1}+Y_{1}\right)(1-\tau)\right](1-\tau)(e+\delta)\right] .
$$

The lefthand size of (A4), $E[d U / d F]$, is the expected marginal benefit of diversification, i.e. the expected marginal utility valuation of the equity premium associated with higher $F$, $d A_{1} / d F=e+\delta$. The righthand side of (A4) is the expected marginal cost of diversification, i.e. the marginal increase in the probability of a sudden stop, $d \phi / d F$, times the utility cost of lost consumption associated with a sudden stop, $U\left[A_{1}+Y_{1}-B\right]-U\left[\left(A_{1}+Y_{1}\right)(1-\tau)\right] .{ }^{4}$

CB management is assumed to focus solely on maintaining financial stability, ignoring the effects of its behavior on the utility of domestic agents. As long as a crisis is avoided, the CB manager enjoys a consumption level of $C_{c b}$, and utility $U\left[C_{c b}\right]$. A financial crisis entails a penalty at rate $p ; 1 \geq p>0$ (possibly involving replacement of the central bank manager), reducing the central bank's utility to $U\left[c_{c b}(1-p)\right]$. In these circumstances, the CB's expected utility is

\footnotetext{
${ }^{4}$ Since $\phi^{\prime}>0$, note that $d \phi / d F=-\phi^{\prime}\left(B / A_{1}\right)(e+\delta)>0$ for a negative shock large enough such that $e+\delta<0$. Note also that the utility cost is positive as long as $\left(A_{1}+Y_{1}\right) \tau>B$, i.e. the penalty costs are greater than the foregone foreign borrowing obligation.
} 


$$
V_{c b}=E\left[\left\{1-\phi\left[B / A_{1}\right]\right\} U\left[C_{c b}\right]+\left\{\phi\left[B / A_{1}\right]\right\} U\left[C_{c b}(1-p)\right]\right]
$$

Consequently, the FOC determining the optimal level of foreign equities for the CB is

$$
d V_{c b} / d F=E\left[\phi^{\prime} \frac{B}{\left(A_{1}\right)^{2}}(e+\delta)\right]=0
$$

Comparing the FOC of optimal portfolio diversification by the SWF, (A3), to the FOC of the $\mathrm{CB}$, (A6), reveals that the CB ignores the possible expected gains to domestic agents induced by diversification in the presence of a positive equity premium. Instead, the CB minimizes the downside risk associated with adverse equity shocks, recognizing that such shocks would increase the leverage ratio $B / A_{1}$ at a rate proportionate to the equity portfolio share (since (A1) implies $\left.A_{1} / A=r_{0}+(e+\delta)(F / A)\right)$, thereby increasing the probability of sudden stops in bad times. This suggests that the CB will opt for much less diversification into foreign equities than the SWF.

Further insight is gained by considering a simple example, where the equity shock, $\delta$, takes on two values, either $\bar{\delta}$ or $-\bar{\delta}$, each with probability one half, implying mean value 0 and standard deviation $\bar{\delta}$. Agents' utility displays constant relative risk aversion, with a CRRA coefficient $\beta$. The left panel of Figure A1 plots the optimal share of foreign equities in a portfolio managed by the SWF (top curve) and the CB (bottom curve), each as a function of volatility $\bar{\delta}$, for the case where the initial public asset position is $A=1$, well below the level of external liabilities, $B$, assumed to be 1.6. With the initial foreign public asset level $A$ normalized to $1, F$ also measures the equity share of the portfolio. For $\bar{\delta}=0.2$, the SWF's diversification rate is roughly $87 \%$, whereas the CB opts for a much lesser degree of diversification (about 15\%). Figure A2 plots the association between the equity shock and the sudden stop probability for the CB (dotted line) and SWF (bold line), given the optimal equity share $F$ chosen when $\bar{\delta}=$ 0.2 , for varying realizations of the equity shock. Note that the limited diversification strategy pursued by the CB results in a relatively low expected probability of sudden stops, less than 0.1. In contrast, the greater holdings of risky foreign equities by the SWF exposes the economy to the greater downside risk of a sudden stop in bad times, e.g. for a $\delta$ realization of -0.4 , the probability of a crisis is almost 0.3 . 
Our framework suggests that, for relatively low levels of public foreign assets, assigning portfolio management independence to the $\mathrm{CB}$ may advantageous. However, for a large enough asset base $A$, the opportunity cost associated with the limited portfolio diversification of the $\mathrm{CB}$ would be high enough to induce the authorities to establish a SWF, treating it as an agent for the Treasury in pursuit of greater returns. In these circumstances, the SWF would opt for much higher greater investment in foreign equities, while the CB would manage its assets with limited diversification, so as to minimize the downside risk of sudden stop crises. The right panel of Figure A1 illustrates the effects of the size of the asset base on diversification choices, by tripling $A$ from 1 to 3 . As can be observed, the higher level of public assets has a negligible effect on the CB's demand for equities, but induces a large increase in the SWF's equity demand.

\section{A2. Delegation of Financial Stability Objective to Central Bank}

This section extends the base model, recognizing the possibility that the $\mathrm{CB}$ has a comparative advantage in avoiding sudden stops and maintaining financial stability, whereas the SWF has a comparative advantage in managing risky portfolios. We continue to assume that $A$, the initial foreign assets of the public sector, and $B$, aggregate foreign borrowing, are exogenously determined. We now assume that the Treasury, is the dominant player, determining the split of the given level of public foreign assets $A$, between the management of the SWF and the $\mathrm{CB}$, while also managing the composition of the SWF's portfolio of foreign assets: $A=A_{s w}+A_{c b}$; where $A_{s w}, A_{c b}$ denote the initial assets managed by the SWF and CB, respectively. Note that if $A$ is given and the CB determines $A_{c b}$, then $A_{s w}$ is determined as well.

The realized value of assets under CB management in the following period are $A_{1, c b}$. The CB diversifies its portfolio between foreign reserves $\left(R_{c b}\right)$ and foreign equities $\left(F_{c b}\right)$,

$$
\begin{aligned}
& A_{c b}=R_{c b}+F_{c b}, \text { implying } \\
& A_{1, c b}=r_{o} A_{c b}+(e+\delta) F_{c b},
\end{aligned}
$$

where $e$ is the expected equity premium and $\delta$ is a zero mean equity-return shock for investment in risky assets by the central bank.

The Treasury has a comparative advantage in active management of the external portfolio, resulting in an equity premium and equity return shock $\left(e_{s w}, \delta_{s w}\right)$ that differs from those affecting the CB's portfolio, $e, \delta$. This reflects the possibility that the $\mathrm{CB}$ diversifies by 
passive portfolio investment channels (such as investing in broad and relatively liquid foreign stock indexes), whereas Treasury diversities by more active portfolio management, including FDI and possibly less liquid projects, with possible exposure to higher expected returns, but with the downside of more volatile returns (hence $e_{s w} \geq e ; \sigma_{\delta_{s w}} \geq \sigma_{\delta}$ ). Accordingly, the realized value of assets under SW management in the following period is $A_{1, s w}$ :

$$
A_{1, s w}=r_{o} A_{s w}+\left(e_{s w}+\delta_{s w}\right) F_{s w}
$$

As before, the probability of a sudden stop, $\phi$, depends positively on the exogenously given level of aggregate foreign liabilities $B$ and negatively on the public sector's foreign assets $A_{1}$, such that $\phi=\phi\left[B / A_{1}\right]$.

As the $\mathrm{CB}$ deals directly with monitoring and supervising financial intermediation, we presume that the CB has a comparative advantage in reducing the probability of a financial crisis triggered by sudden stops, implying that, for a given ratio of foreign borrowing to assets, the CB's management results in a lower probability of sudden stops than would that of the SWF, i.e. $\phi_{c b}[x]<\phi_{s w}[x]$, where $\phi_{c b}[x] ; \phi_{s w}[x]$ denote the sudden stop probability if assets are managed by the CB and a Treasury-controlled SWF, respectively, and $x=B / A_{1}{ }^{5}$

The cost of delegating financial stability management to the CB is that, in case of need, only a fraction $q$ of $A_{s w}$ would be available to the $\mathrm{CB}(0 \leq q<1)$. This may reflect both the lower liquidity of the SWF's investment, and institutional frictions that may slow down the SWF's ability to mobilize resources. Hence, under CB management, $\phi_{c b}[x]=\phi_{c b}\left[B /\left(A_{1, c b}+q A_{1, s w}\right)\right]$. For simplicity, we assume that $q=0$, implying $\phi_{c b}[x]=\phi_{c b}\left[B / A_{1, c b}\right]$.

The diversification problem facing the $\mathrm{CB}$ is identical to the one described in section $\mathrm{A} 1$, i.e. maximize with respect to $F_{c b}$ the objective function

$$
V_{c b}=E\left[\left\{1-\phi_{c b}\left[B / A_{1, c b}\right]\right\} U\left[C_{c b}\right]+\left\{\phi_{c b}\left[B / A_{1, c b}\right]\right\} U\left[C_{c b}(1-p)\right]\right]
$$

\footnotetext{
${ }^{5}$ One way to capture the CB's comparative advantage is to suppose that $\phi_{c b}=(1-b) \phi_{s w} ; \quad 0<b<1$, where $b$ measures the delegation gain associated with assigning the financial stability objective to the $\mathrm{CB}$. In these circumstances, delegation implies that the CB will choose a more prudent policy than the one chosen by the SWF. The financial stability delegation to the CB makes the Treasury and SWF better off if the efficiency gains associated with CB's comparative advantage are sizable enough (i.e., for large enough $b$ ).
} 
subject to (A1'), where $\phi$ is replaced with $\phi_{c b}$ and $B$ and $A_{c b}$ are exogenous to the CB's actions. Hence an analogue to the first order condition (A6) holds:

$$
d V_{c b} / d F_{c b}=E\left[\phi_{c b}^{\prime} \frac{B}{\left(A_{1, c b}\right)^{2}}(e+\delta)\right]=0 .
$$

The SWF's expected utility is akin to (A2), modified by delegating the financial stability objective to the $\mathrm{CB}$ :

$$
V_{s w}=E\left[\left\{1-\hat{\phi}_{c b}\left[A_{c b} ; B\right]\right\} U\left[A_{1, s w}+Y_{1}-B\right]+\left\{\hat{\phi}_{c b}\left[A_{c b} ; B\right]\right\} U\left[\left(A_{1, s w}+Y_{1}\right)(1-\tau)\right]\right]
$$

where $\hat{\phi}_{c b}$ is the probability of a sudden stop as determined by CB policy, which in turn is conditional on the CB's initial foreign asset holdings set by the Treasury $A_{c b}$ as well as (exogenous) foreign borrowing $B .^{6}$

The Treasury's problem is to determine, for given initial public assets $A$, the SWF's investment in equities $F_{s w}$ and the optimal level of initial CB assets $A_{c b}$, that maximize (A2'), subject to

$$
A_{1, s w}=r_{o}\left(A-A_{c b}\right)+\left(e_{s w}+\delta_{s w}\right) F_{s w} ; \quad 0 \leq F_{s w} \leq A_{s w} \leq A
$$

(Recall that setting $A_{c b}$ also determines the SWF's safe asset holdings $A_{s w}$, since $A_{s w}=A-A_{c b}$.)

The first-order condition for optimal $F_{s w}$ and asset diversification by the SWF is

$$
E\left[\left[\left\{1-\hat{\phi}_{c b}\right\} U^{\prime}\left[A_{1, s w}+Y_{1}-B\right]+\left\{\hat{\phi}_{c b}\right\} U^{\prime}\left[\left(A_{1, s w}+Y_{1}\right)(1-\tau)\right](1-\tau)\right]\left(e_{s w}+\delta_{s w}\right)\right]=0
$$

or $E\left[d U_{s w} / d F_{s w}\right]=0$. Comparing (A8) to (A4), we infer that delegating financial stability policy to the CB implies that the SWF equates the expected marginal benefit of diversification, $E\left[d U_{s w} / d F_{s w}\right]$, to zero, instead of equating it to the expected cost of increasing the sudden stop probability.

Figure A3 illustrates the effect of policy delegation on the SWF's degree of diversification. The bottom curve shows the SWF's diversification pattern in the absence of delegation, corresponding to the case depicted in the left panel of A1 (with the same parameter values, including $a=20$ ). The top curve (labeled “SWF, CB delegation”) corresponds to the

\footnotetext{
${ }^{6}$ (A6') yields an expression for $F_{c b}$ as an implicit function of $A_{c b}$, as well as $B$ and $e+\delta: F_{c b}=F_{c b}\left[A_{c b} ; B, e, \sigma_{\delta}\right]$. Substituting $F_{c b}$ into $\phi$ gives $\phi_{c b}=\phi_{c b}\left[B / A_{1, c b}\right]=\phi_{c b}\left[B /\left(r_{0} A_{c b}+F_{c b}\left[A_{c b}\right](e+\delta)\right)\right] \equiv \hat{\phi}_{c b}\left[A_{c b} ; B\right]$.
} 
SWF's diversification pattern with the same asset base $\left(A_{s w}=1\right)$, in circumstances where the CB is assigned the objective of minimizing the probability of a sudden stop (for the case where $A_{c b}=1, a=10$ ). With delegation, for any given volatility of returns, the SWF chooses to hold a higher level of foreign equity assets, implying greater diversification.

Our framework also implies that, as part of its optimal portfolio policy, the Treasury determines the CB's initial foreign assets, $A_{c b}$. The discussion above implies that, above a threshold of foreign assets $A$, marginal increases in $A$ lead to greater asset allocation by the Treasury to the SWF. This holds trivially as the probability of sudden stop, $\hat{\phi}_{c b}$, approaches zero.

More generally, the first-order condition determining $A_{c b}$ is:

$$
\begin{aligned}
d V_{s w} / d A_{c b}= & E\left[\left(\left\{1-\hat{\phi}_{c b}\right\}\left(-U^{\prime}\left[A_{1}+Y_{1}-B\right]\right)+\left\{\hat{\phi}_{c b}\right\}\left(-U^{\prime}\left[\left(A_{1}+Y\right)(1-\tau)\right]\right)(1-\tau)\right)\left(r_{o}+(e+\delta) F^{\prime}{ }_{c b}\right)\right] \\
& +E\left[\left(-\hat{\phi}_{c b}^{\prime} \frac{B}{\left(A_{1, c b}\right)^{2}}\left(r_{o}+(e+\delta) F^{\prime}{ }_{c b}\right)\left\{U\left[A_{1}+Y_{1}-B\right]-U\left[\left(A_{1}+Y\right)(1-\tau)\right]\right\}\right)\right]=0
\end{aligned}
$$

or

$$
E\left[d U / d A_{c b}\right]=E\left[-\hat{\phi}_{c b}^{\prime} \frac{B}{\left(A_{1, c b}\right)^{2}}\left(r_{o}+(e+\delta) F_{c b}^{\prime}\right)\left\{U\left[A_{1}+Y_{1}-B\right]-U\left[\left(A_{1}+Y\right)(1-\tau)\right]\right\}\right]=0
$$

where

$$
E\left[d U / d A_{c b}\right] \equiv E\left[\left\{1-\hat{\phi}_{c b}\right\} U^{\prime}\left[A_{1}+Y_{1}-B\right]+\left\{\hat{\phi}_{c b}\right\} U^{\prime}\left[\left(A_{1}+Y\right)(1-\tau)\right](1-\tau)\left(r_{o}+(e+\delta) F^{\prime}{ }_{c b}\right)\right] .
$$

Thus the Treasury extends more initial foreign assets to the central bank to the point that the expected marginal benefit of doing so, $E\left[d U / d A_{c b}\right]$, i.e. the expected marginal utility valuation of the return associated with higher $A_{c b}--d A_{1, c b} / d A_{c b}=r_{o}+(e+\delta) F^{\prime}{ }_{c b}$, where $F_{c b}{ }_{c b}$ is the marginal impact on the CB's optimal foreign equity holdings ${ }^{7}$-- equals the marginal increase in the probability of a sudden stop, $\hat{\phi}_{c b}^{\prime}$, times the utility cost of a sudden stop, $U\left[A_{1}+Y_{1}-B\right]-U\left[\left(A_{1}+Y_{1}\right)(1-\tau)\right]$.

\footnotetext{
${ }^{7}$ As noted earlier, (A6') yields an expression for $F_{c b}$ as an implicit function of $A_{c b}$, as well as $B$ and $e+\delta$ : $F_{c b}=F_{c b}\left[A_{c b} ; B, e, \sigma_{\delta}\right]$.
} 


\section{A3. Domestic and External Transparency}

We conclude with a short discussion about the impact of transparency on the behavior of a SWF. We denote domestic and international transparency indices by $t_{\text {dom }}, t_{\text {intl }}$, respectively. Domestic transparency determines the opaqueness of the SWF to domestic tax payers. If greater domestic transparency increase the median voter's support for the SWF, greater resources may be delegated to it, implying $A=A\left[t_{\text {dom }}\right], A^{\prime}>0 .^{8} \quad$ In less democratic countries, SWF management may reflect the preferences of a narrow power group, and the determination of internal transparency is more involved. Too little transparency may backfire by fueling popular dissent, encouraging political instability, and possibly reducing the tenure of the Treasury management by its forceful removal from office. Yet, "high” domestic transparency may entail another cost to the Treasury in the form of greater discontent, inducing other power groups to challenge the size and the mandate of the SWF. In these circumstances, the association between the resources available to the Treasury and domestic transparency may have an inverted U-shape, $A=A\left[t_{\text {dom }}\right], \quad A^{\prime}>0, A^{\prime \prime}<0 .^{9}$

Similarly, international transparency refers to the degree to which the holdings and the investment strategy of the SWF is transparent to the global financial system. The SWF may face a complex trade off regarding international transparency. If the SWF benefits from access to superior talent and information, greater transparency may reduce the effectiveness of any proprietary strategy used by the fund. Yet, inadequate international transparency tends to reduce the hospitality shown towards FDI and portfolio investment in the host country and possibly encourage local efforts to reduce SWF's access to profitable business opportunities. This

\footnotetext{
${ }^{8}$ In a more general framework these levels of transparency may be determined endogenously.

${ }^{9}$ The Treasury's solution may entail running “double accounting books," where official figures may understate actual SWF accumulations and allocations. One can model this behavior in a version of a principal-agent model, extending Hermalin and Weisbach (2007). The Treasury, as the principal, manages the SWF, determining its transparency. The agents consist of tax payers and other power groups. Monitoring the principal entails a political struggle that is costly to both the principal (possibly through the loss of control), and agents (exposed to possible violence and punishment). In these circumstances, if agents believe that the gap between the official and the actual books is not "large," they will tolerate an equilibrium with limited domestic transparency. The principal then determines the "optimal" level of domestic transparency" taking into account that low transparency allows it to gain by increasing the gap between the actual and official books, balanced against the cost of increasing the probability of losing control.
} 
suggests that the association between excess equity returns and the SWF's international transparency may have an inverted U shape, $e_{s w}=e_{s w}\left[t_{\text {intl }}\right], e_{s w}^{\prime}<0, e_{s w}^{\prime \prime}>0 .^{10}$

In our benchmark model, increases in domestic transparency can be interpreted as parametric shifts in $A$. As depicted in Figure 1b, in the case that greater transparency primarily increases the level of foreign assets allocated to the SWF, the level of investment in foreign equity assets raises significantly for any given volatility level $\bar{\delta} \cdot{ }^{11}$ Similarly, if the degree of international transparency increases enough to raise the expected return to foreign assets, the SWF's foreign equity investment increases as well.

\footnotetext{
${ }^{10}$ SWF size also may play an important role: limited transparency by larger funds may encourage greater hostility to investment in foreign markets, possibly owing to the fear that a large player may use its market clout strategically, such as for mercantilist trade goals.

${ }^{11}$ In our framework with responsibility for financial stability delegated to the central bank, the Treasury sets $A_{c b}$, given $A$, while the CB determines $F_{c b}$, given $A_{c b}$. But setting $A_{c b}$ also determines the SWF's safe asset holdings $A_{s w}$, since $A_{s w}=A-A_{c b}$. In this case $A_{s w}$ depends on $t_{\text {dom }}$ only through $A$ : an increase in domestic transparency that results in greater initial public foreign entrusted to the Treasury also is associated with greater assets entrusted to the sovereign wealth fund.
} 
Figure A1. Equity return volatility, foreign equity holdings, and asset size

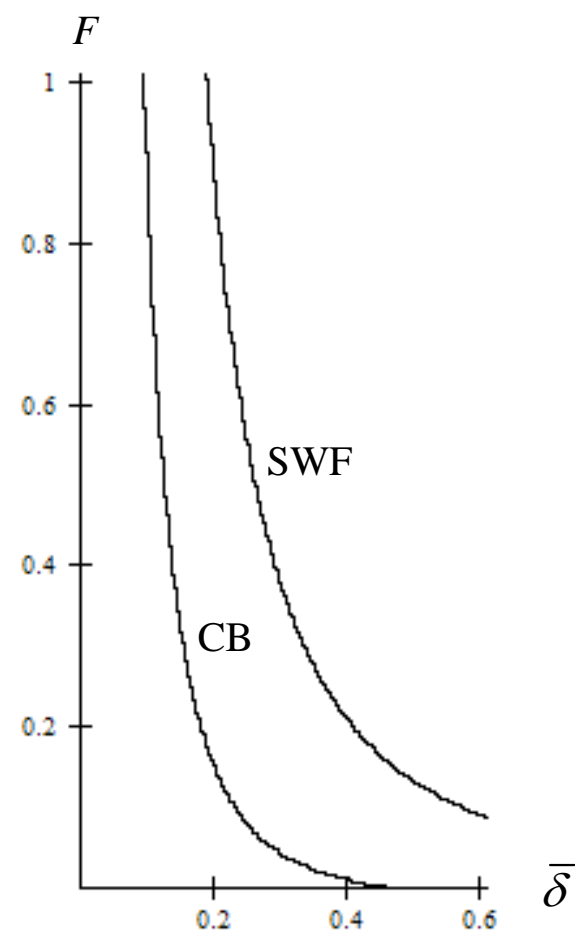

$A=1$

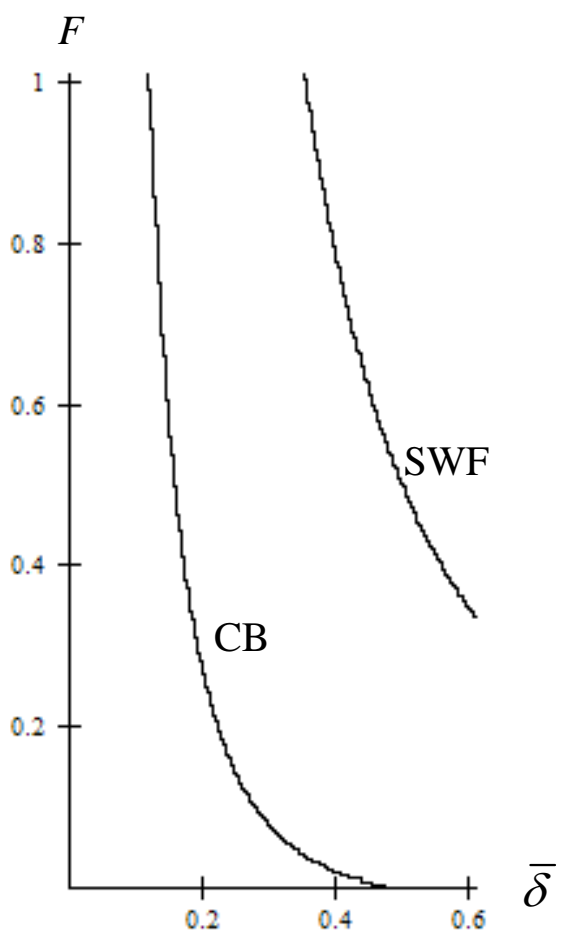

$A=3$

Note: The bottom (top) curve corresponds to the CB behavior (SWF). Simulation assumes $\phi=\operatorname{MIN}\left\{a\left[B /\left(A_{1}+B\right)\right]^{h} ; 1\right\}$, the equity shock, $\delta$, takes on two values, either $\bar{\delta}$ or $-\bar{\delta}$, and $r_{0}=0, \beta=2, Y_{1}=2, B=1.6, e=0.05, \tau=0.2, p=0.9, h=12, a=20$. The lefthand and righthand panels assume initial asset size levels $A$ of 1 and 3 , respectively.

Figure A2. Equity return shock realizations and probability of sudden stop.

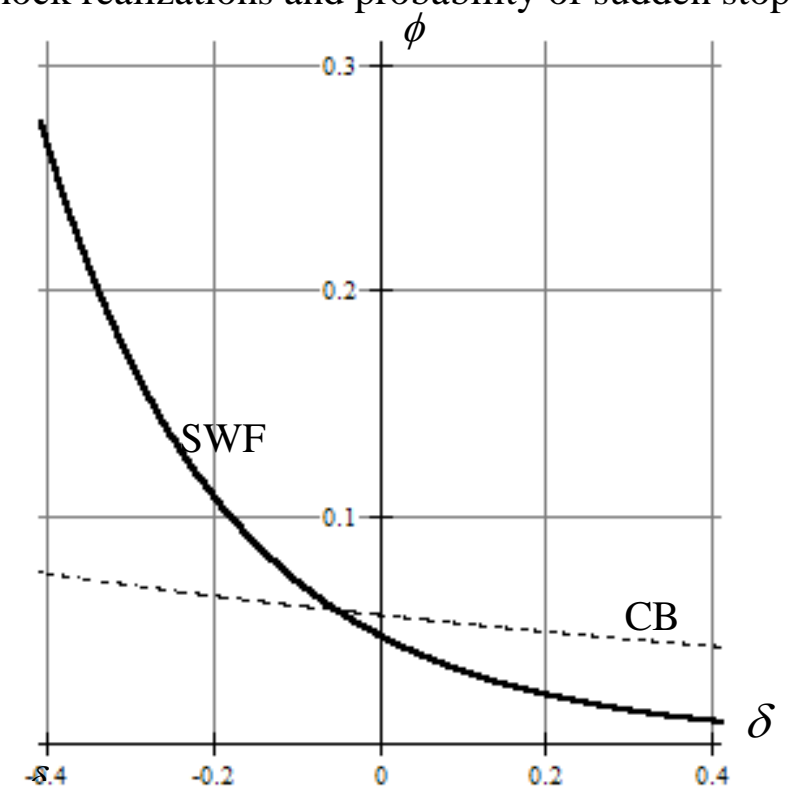

Note: Simulation assumes $F_{c b}=0.15 ; F_{s w}=0.87 ; A=1$, and the parameters specified in Figure A1. The bold curve draws the sudden stop probability for $F=0.87$ (the SWF equity share for volatility level $\delta=0.2$ ), while the dotted curve draws the sudden stop probability for $F=0.15$ (the CB equity share for volatility 0.2 ). 
Figure A3. Equity return volatility and diversification rate for SWF, with and without CB delegation

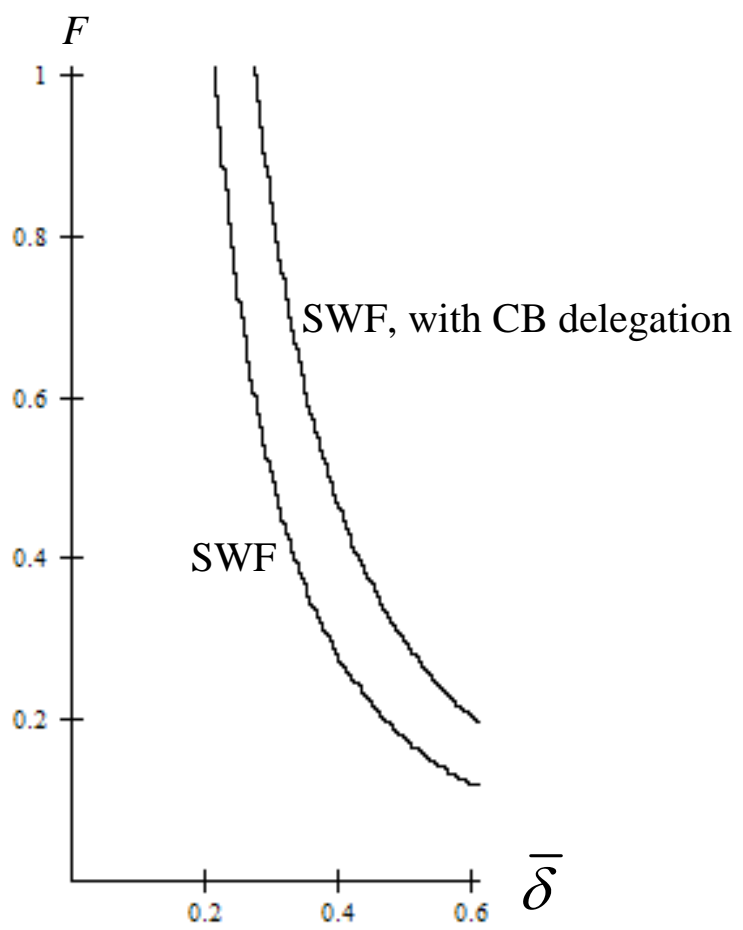

Note: Bottom curve describes SWF diversification in the absence of delegation. The simulation assumes $\phi_{s w}=\operatorname{MIN}\left\{a\left[B /\left(A_{1}+B\right)\right]^{h} ; 1\right\}$, the equity shock, $\delta$, takes two on values, either $\bar{\delta}$ or $-\bar{\delta}$, and $r_{0}=0, \beta=2, Y_{1}=2, A_{S W}=1, B=1.6, e=0.05, \tau=0.2, p=0.9, h=12, a=20$. The top curve describes SWF behavior with delegation, where $A_{s w}=1, \quad A_{c b}=1$, and $\phi_{c b}=\operatorname{MIN}\left\{0.5 a\left[B /\left(A_{1, c b}+B\right)\right]^{h} ; 1\right\}$ 